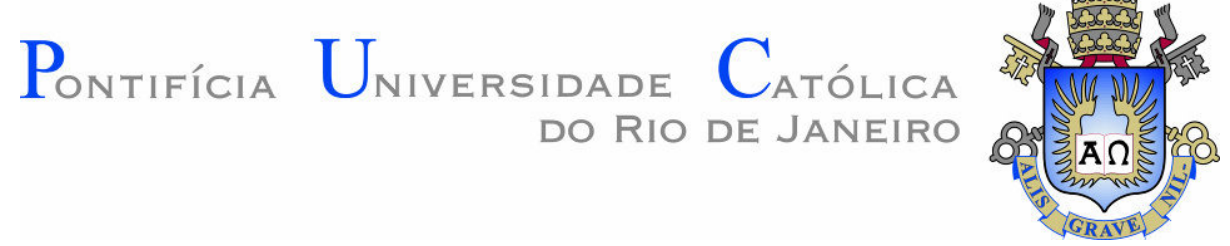

Gidy Carolina Florez Navarro

\title{
Sistema Simples em VHDL para o Desenvolvimento de um Setup de Múltiplas Antenas.
}

Dissertação de Mestrado

Dissertação apresentada como requisito parcial para obtenção do grau de Mestre pelo Programa de Pós-graduação em Engenharia Elétrica do Departamento de Engenharia Elétrica da PUC-Rio

Orientador: Prof. Gláucio Lima Siqueira 


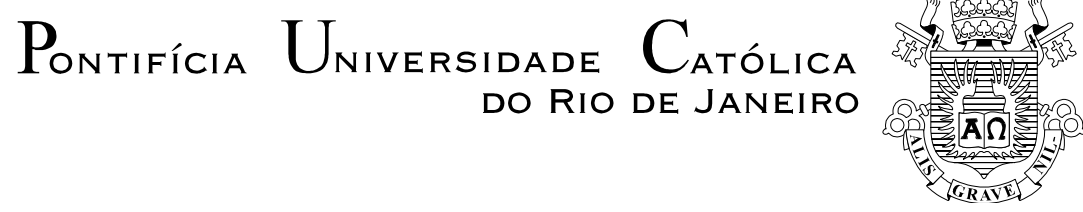

Gidy Carolina Florez Navarro

Sistema Simples em VHDL para o Desenvolvimento de um Setup de Múltiplas Antenas

Dissertação de Mestrado apresentada como requisito parcial para obtenção do grau de Mestre pelo Programa de Pós-Graduação em Engenharia Elétrica do Departamento de Engenharia Elétrica do Centro Técnico Científico da PUC-Rio. Aprovada pela Comissão Examinadora abaixo assinada.

Prof. Glaucio Lima Siqueira Orientador Centro de Estudos em Telecomunicações - PUC-Rio

Prof. Luiz Alencar Reis da Silva Mello Centro de Estudos em Telecomunicações - PUC-Rio

Profa. Leni Joaquim de Matos

UFF

Prof. Marbey Manhães Mosso Centro de Estudos em Telecomunicações - PUC-Rio

Prof. José Eugenio Leal Coordenador Setorial do Centro

Técnico Científico - PUC-Rio 
Todos os direitos reservados. É proibida a reprodução total ou parcial do trabalho sem autorização da universidade, do autor e do orientador.

\section{Gidy Carolina Florez Navarro}

Graduada em Engenharia Eletrônica com ênfase em telecomunicações pela Universidad Autónoma del Caribe em 2010. Atuais linhas de pesquisa: Sistemas Rádio Celular, Sistemas MIMO, circuitos digitais lógicos programáveis em linguagem VHDL (FPGA e CPDLs).

Navarro, Gidy Carolina Florez

Sistema Simples em VHDL para o Desenvolvimento de um Setup de Múltiplas Antenas/ Gidy Carolina Florez Navarro; orientador: Gláucio Lima Siqueira. - Rio de Janeiro : PUCRio, Departamento de Engenharia Elétrica, 2012.

75 f: il.(color.) ; $30 \mathrm{~cm}$

1. Dissertação (mestrado) - Pontifícia Universidade Católica do Rio de Janeiro, Departamento de Engenharia Elétrica.

Inclui referências bibliográficas.

1. Engenharia Elétrica - Tese. 2. MIMO. 3. Canal 4. Capacidade. 5. Ganho de diversidade. 6. Ganho de multiplexação. 7. VHDL. 8. Razão de proteção. 9. Margem de Proteção. I. Siqueira, Gláucio Lima. II. Pontifícia Universidade Católica do Rio de Janeiro. Departamento de Engenharia Elétrica. III. Título. 


\section{Agradecimentos}

Aos meus pais, Gonzalo e Maria Inês, pelo apoio e ajuda para poder viajar a um país estrangeiro e serem os promotores deste passo grande na minha vida e carreira.

Ao meu orientador, prof. Gláucio Lima Siqueira, pela compreensão e apoio no caminho de minha dissertação.

Ao professor Marbey Mosso, quem ajudou-me no processo do projeto na parte de microondas, brindou-me com sua disposição com os equipamentos do laboratorio GSOM, materiais e softwares utilizados na tese que foram ponto indispensável para o desenvolvimento deste.

Aos colegas do CETUC, a Vanessa por me brindar com sua ajuda toda vez que eu precisei, além de me ajudar com a revisão do texto. À Gelza pela sua disposição sempre com conhecimento, na área de teste e simulação de antenas e à Juliana, pela ajuda, paciência e amizade nesses dois anos de estudo no mestrado.

Ao meu namorado Félix, pela assistência nos obstáculos em Matlab, também pelo ânimo, preocupação e apoio no caminho da minha dissertação e da minha vida.

Aos colegas Leonel e Byron, pelas orientações no processamento do sinal e ajuda em Matlab. VHDL.

Ao Heiner Castro, pela ajuda com as numerosas dúvidas que tive em

Finalmente, à Pontifícia Universidade Católica de Rio de Janeiro (PUCRio), pelo apoio académico e, o apoio financeiro provido pela Coordenação de Aperfeiçoamento de Pessoal de Nível Superior - CAPES pois graças a eles o meu estudo de mestrado e este trabalho poderam ser realizados . 


\section{Resumo}

Navarro, Gidy Carolina Florez; Siqueira, Gláucio Lima. Sistema Simples em VHDL para o Desenvolvimento de um Setup de Múltiplas Antenas. Rio de Janeiro, 2012. 75p. Dissertação de Mestrado - Departamento de Engenharia Elétrica, Pontifícia Universidade Católica do Rio de Janeiro.

Os sistemas MIMO (Multiple In - Multiple Out) são o surgimento de novos sistemas de telecomunicações, tendo o recurso para gerar maior capacidade de canal com transmissores de baixa potência, criando uma utilização mais eficiente da energia. Como o objetivo é proporcionar uma maior taxa de dados, os métodos convencionais são muito limitados, assim os sistemas MIMO geram um aumento em capacidade e confiabilidade e prometem ser concorrência para sistemas 4G, aprimorando as técnicas de multiplexação e diversidade, ajudando a aumentar a taxa de transmissão, mantendo os mesmos níveis de potência de um sistema convencional. Desta forma, o estudo e aprimoramento das técnicas de medições do canal MIMO são de extrema importância para verificar a confiabilidade da transmissão de dados por múltiplas antenas, as técnicas de modulação assim como a capacidade do canal. Neste trabalho quatro antenas planares aplicadas ao sistema MIMO são dimensionadas, simuladas e realizadas, comparando resultados experimentais com simulados. Apresenta-se também o desenvolvimento de um transmissor e um receptor simulado pelo System Vue (Agilent) e implementado em VHDL.

\section{Palavras-chave}

MIMO; Canal; Capacidade; Ganho de diversidade; Ganho de multiplexação; VHDL. 


\section{Abstract}

Navarro, Gidy Carolina Florez; Siqueira, Gláucio Lima(Advisor). VHDL Simple System for Developing a Setup of Multiple Antennas. Rio de Janeiro, 2012. 75p. MSc. Dissertation - Departamento de Engenharia Elétrica, Pontifícia Universidade Católica do Rio de Janeiro.

MIMO systems (Multiple In - Multiple Out) are the rise of new telecommunication systems. They have the characteristic of generating greater channel capacity with low power transmitters, creating a more efficient use of energy. As the purpose is to provide higher data rate, conventional methods are too limited to improve this, and MIMO systems generate an increase in capacity and reliability, also they promise to be competition for $4 \mathrm{G}$ systems improving multiplexing and diversity techniques which helps to increase the transmission rate while maintaining the same power levels of a conventional system. Thus, the study and improvement of techniques for MIMO channel measurements are extremely important to check the reliability of data transmission from multiple antennas, modulation techniques as well as the channel capacity. In this work four planar antennas applied to the MIMO system are scaled, simulated and performed by comparing experimental results with simulations. Also present the development of a transmitter and a receiver simulated by SystemVue (Agilent) and implemented in VHDL.

\section{Keywords}

MIMO ; Channel; Capacity; Diversity gain; Multiplexing gain; VHDL. 


\section{Sumário}

1 Introdução 11

2 MIMO $\quad 13$

2.1 Como ele funciona? 13

$\begin{array}{ll}2.2 \text { Vantagens } & 13\end{array}$

2.3 MIMO e Smart Antennas 14

2.4 Modelo MIMO de Banda Estreita 15

2.5 Conclusões 18

3 Desvanecimento $\quad 19$

$\begin{array}{ll}3.1 \text { Desvanecimento em larga escala } & 19\end{array}$

3.2 Desvanecimento em pequena escala 19

3.3 Mitigação do desvanecimento 20

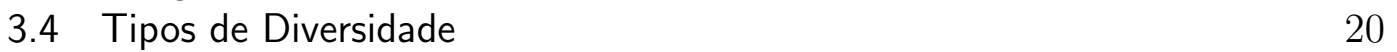

3.5 Técnicas de Diversidade $\quad 21$

3.6 Ambiente multipercurso 24

3.7 Canal de desvanecimento plano tipo Rayleigh 25

3.8 Conclusões 27

4 Sistema MIMO 2x2 $\quad 28$

4.1 Transmissor 28

4.2 Receptor 34

$\begin{array}{ll}4.3 & \text { Capacidade MIMO } \\ & 38\end{array}$

$\begin{array}{lll}4.4 \text { Conclusões } & 40\end{array}$

5 Antenas $\quad 41$

5.1 Antena Patch Retangular 42

5.2 Conclusões 45

6 Desenvolvimento do sistema MIMO 2×2 $\quad 47$

$\begin{array}{lll}6.1 & \text { Ferramentas utilizadas } & 48\end{array}$

6.2 Simulação do Transmissor $\quad 49$

6.3 Simulação do Canal $\quad 51$

6.4 Simulação do Receptor 53

6.5 Fabricação das Antenas $\quad 59$

6.6 Conclusões 64

7 Comentários finais e conclusões $\quad 68$

$\begin{array}{lll}7.1 & \text { Trabalhos futuros } & 69\end{array}$

$\begin{array}{ll}\text { A Anexo } & \mathbf{7 4}\end{array}$ 


\section{Lista de figuras}

2.1 Beamforming 14

$\begin{array}{ll}2.2 \text { Diversidade } & 15\end{array}$

2.3 Smart Antennas $\quad 15$

2.4 Sistema MIMO 16

2.5 Modelo do canal no sistema MIMO 16

2.6 Matriz do canal no sistema MIMO 16

3.1 Diversidade em Frequência 21

3.2 Diversidade no Tempo 22

3.3 Diversidade de Espaço 23

3.4 Resposta ao impulso de um canal multipercurso 25

4.1 Transmissor para o sistema MIMO 28

4.2 Multiplexação Espacial 29

4.3 Processo do SVD 31

4.4 Subcanais paralelos 33

4.5 Constelação BPSK 34

4.6 Receptor para o sistema MIMO 35

5.1 Antena de microfita 41

5.2 Linhas de campo e constante dielétrica efetiva em uma linha de microfita

5.3 Cenário de diversidade espacial 44

5.4 Coeficiente de correlação espacial em função de $d / \lambda$ e de $a / b$. $\xi=90^{\circ}$

6.1 Sistema MIMO 2x2 47

6.2 Bloco do Transmissor feito em VHDL 49

6.3 Visão do bloco HDL $\quad 50$

6.4 Gráfico do sinal gerado e sua multiplexação 50

6.5 Mapeamento em BPSK dos sinais multiplexados 51

6.6 Bloco de simulação do canal Rayleigh feito mediante código em Matlab $\quad 52$

6.7 Visão interna do bloco do simulador de canal 52

6.8 Sinais da saida da transmissão alterados pelos efeitos do canal Rayleigh

6.9 Bloco do Receptor 54

6.10 Conteúdo do bloco de conversão de fixo a real 55

6.11 Seção do equalizador dentro do bloco do receptor $\quad 55$

6.12 Detetor de limiar e multiplexador 56

6.13 Sinal equalizado com o MMSE $\quad 57$

6.14 Sinal reconstruído, comparado com o sinal do transmissor $\quad 57$

6.15 Taxa de erro de bit versus relação sinal-ruído do sistema 58

6.16 Comparação da capacidade $\times$ SNR em um sistema $\mathrm{SISO}(1 \times 1)$, MISO(2x1), $\operatorname{SIMO}(1 \times 2)$ e MIMO 2x2 
6.17 Medidas da antena para uma frequência de $10 \mathrm{GHz}$ feita no software ADS

6.18 Simulação e medição da perda de retorno, em dB, para cada uma das antenas fabricadas para frequência aproximada de $10 \mathrm{GHz}$

6.19 Array de 4 antenas fabricadas sobre o substrato RT5880 para uma frequência de $10 \mathrm{GHz}$

6.20 Comparação da simulação do plano E entre uma antena de microfita e um array de 4 antenas de microfita para uma frequência de $10 \mathrm{GHz}$, com igual substrato (RT5880

6.21 Sistema utilizado para fazer as medições de diagrama de radiação das antenas fabricadas

6.22 Montagem do kit do LabVolt para as medições das antenas desenvolvidas

6.23 Montagem da medição de correlação entre duas antenas dependendo da distância

6.24 Diagrama de radiação da Antena 1

6.25 Diagrama de radiação da Antena $2 \quad 64$

6.26 Diagrama de radiação da Antena $3 \quad 65$

6.27 Diagrama de radiação da Antena 4

6.28 Diagrama de radiação do Array de 4 antenas 66

6.29 Comparação entre diagramas de radiação de acordo com as distâncias de separação entre duas antenas

7.1 Esquema de transmissão e recepção do sistema MIMO proposto 70

A.1 Divisor de potência $\quad 74$

A.2 Simulação do S11 do divisor de potência no software ADS 75 
All glory comes from daring to begin

, Eugene F. Ware. 


\section{Introdução}

$\mathrm{Na}$ era das telecomunicações existe um crescimento acelerado de tecnologias, para a melhoria das necessidades básicas, e as novas que vão se gerando no desenvolvimento da convergência de rede e acabam levando um maior acesso de comunicação de forma integrada, com superiores larguras de banda, confiabilidade e desempenho.

A fim de acompanhar este desenvolvimento, sabe-se que a melhoria dos parâmetros acima é a chave para a utilização de novos sistemas, onde para isso exigiria níveis mais elevados de potência, dependendo de quanto de capacidade será usado. Esta é uma limitação que leva à procura de métodos ou arranjos novos para manter esses níveis de consumo de potência baixos e, ainda, aumentando a taxa de transmissão no sistema.

Estes sistemas são afetados na transmissão por desvanecimentos e interferências e, assim, é difícil recuperar o sinal na recepção. Abordagens são, portanto, necessárias para melhorar a largura de banda e a confiabilidade dos sistemas, então, são usadas algumas técnicas para ajudar a reduzir as distorções.

Uma solução que pode ser aplicada para melhorar os sistemas de telecomunicações é o uso de arrays de antenas no transmissor e no receptor, portanto, dando origem a dois tipos de ganho: de diversidade e de multiplexação, no qual é a maior vantagem obtida fazendo esses arranjos. Estes sistemas são conhecidos como MIMO (Multiple-Input Multiple-Output), que se refere a múlitplas entradas e múltiplas saidas.

Neste cenário, a presente dissertação tem como objetivos:

- Desenvolvimento de un sistema MIMO com duas antenas transmissoras e duas antenas receptoras mediante programação em linguagem de alto 
nível VHDL, para uma futura aplicação na tecnologia FPGA.

- Simulação da variação dos parâmetros característicos de um sistema MIMO, tais como: a capacidade e a taxa de erro de bit, para comparação de resultados e conclusões de melhor desempenho.

- Desenvolvimento, simulação e medição das antenas a utilizar no sistema MIMO para uma frequência de $10 \mathrm{GHz}$ e comparar mediante os diagramas de radiação o melhor arranjo de distância entre as antenas do array.

Na organização do texto serão apresentados 6 capítulos no qual o primeiro capítulo é a introdução já mostrada. O segundo capítulo refere-se á tecnología estudada, especificando o funcionamento e as vantagens que possui. O capítulo 3 aborda o tema relacionado aos efeitos sofridos pelo desvanecimento ou fading, as técnicas de mitigação e o modelo de canal usado na dissertação. Ao longo do capítulo 4 é introduzida a teoria necessária para o desenvolvimento do sistema MIMO na presente dissertação, tais como o transmissor, receptor e antenas a realizar, para que no capítulo 5 poda ser entendido como foi realizado o sistema de múltiplas antenas nas ferramentas empregadas e na linguagem VHDL; além dos resultados obtidos nas simulações do sistema. Finalmente, no capítulo 6 serão apresentados os comentários finais e conclusões da presente dissertação. 


\section{2 \\ MIMO}

Ao longo deste capítulo será introduzida uma visão geral de um sistema MIMO, seu funcionamento, as vantagens e como é o modelo matricial do sistema. Ao utilizar um arranjo de antenas se aumenta a confiabilidade do sistema, assegurando que o sinal atingirá o receptor com uma adequada relação sinal-ruído (SNR) para obter a informação com menores alterações. Deste modo, aproveita-se o fenômeno de multipercurso para enviar o sinal em ambientes onde há muitos obstáculos e dependendo do número de antenas, a capacidade do canal do sistema irá variar implicando na maior complexidade da recepção do sinal.

\section{1}

\section{Como ele funciona?}

Como mencionado, este tipo de arranjo utiliza o fenômeno de multipercurso no qual os sinais das antenas transmissoras se propagam no ambiente e refletem nos obstáculos até chegarem ao destino final. O receptor usa um algoritmo ou sistema de processamento de sinal para a classificação dos múltiplos sinais e, assim, obtém-se um sinal que tem a informação originalmente enviada pelo transmissor.[1]

\section{2}

\section{Vantagens}

Um sistema de múltiplas antenas de transmissão e recepção inclui os seguintes benefícios:

Diversidade de Transmissão em Espaço Tempo (STTD): A mesma informação é codificada e transmitida através de diferentes antenas, o que faz 
aumentar a relação sinal-ruído sem necesidade de aumentar a potência.

Multiplexação espacial (SM): Entrega streams paralelos de informação para o terminal móvel usando o fenômeno de multipercurso, que, dependendo do conjunto de antenas, aumenta a capacidade do canal e o throughput.

Uplink Collaborative MIMO link: Aproveita o uso de um amplificador operacional simples no dispositivo. Dois dispositivos podem transmitir de forma colaborativa no mesmo sub-canal, que também dobra a capacidade de uplink.[1]

\section{3}

\section{MIMO e Smart Antennas}

A primeira vista, sistemas MIMO e Smart Antennas podem parecer iguais, pois ambos incluem múltiplas antenas separadas, tão longe quanto possível. Smart Antennas usa beamforming e diversidade, mas não multiplicam a confiabilidade da informação no canal sem fio como um sistema MIMO faz.

A figura 2.1 apresenta a técnica de beamforming, onde emprega duas antenas transmisoras para entregar o melhor sinal multipercurso a uma antena receptora.

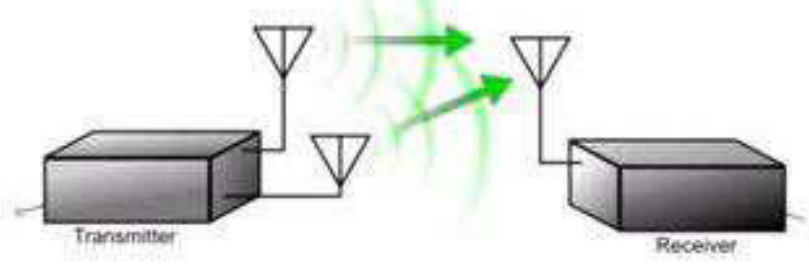

Figura 2.1: Beamforming

A figura 2.2 ilustra o fenômeno de diversidade, no qual utiliza várias antenas receptoras para capturar o melhor sinal multipercurso enviado por uma antena transmissora. 


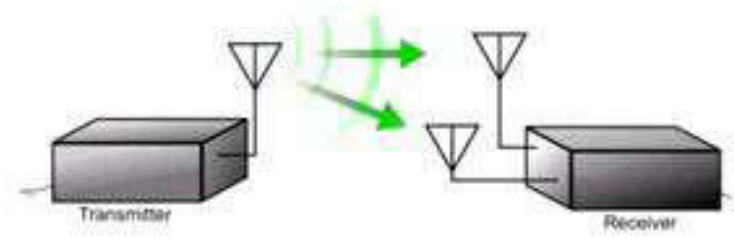

Figura 2.2: Diversidade

Agora, ao se combinar as duas técnicas, o sinal melhorará em qualidade e aumentará um ou dois b/s/Hz, mas apenas um sinal é transmitido através do canal.

A diferença com as antenas inteligentes (Smart Antennas)é que o sistema MIMO usa múltiplas antenas no transmissor e no receptor, enviando múltiplos sinais através do mesmo canal, multiplicando a eficiência espectral. Esta diferença é ilustrada nas figuras 2.3 e 2.4.[2]

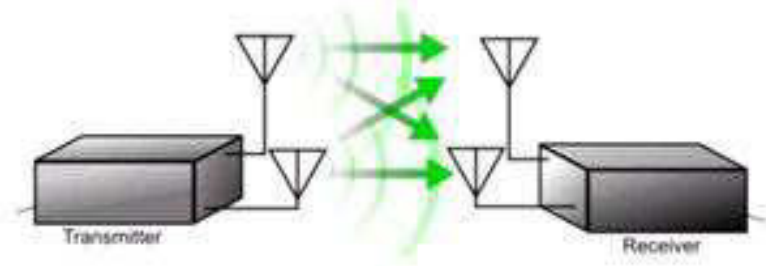

Figura 2.3: Smart Antennas

\section{4}

\section{Modelo MIMO de Banda Estreita}

Consideramos um canal de banda estreita MIMO onde um sistema de comunicação ponto a ponto de $N_{t}$ antenas de transmissão e $N_{r}$ antenas de recepção são representados pelo modelo de tempo discreto da figura 2.5. 


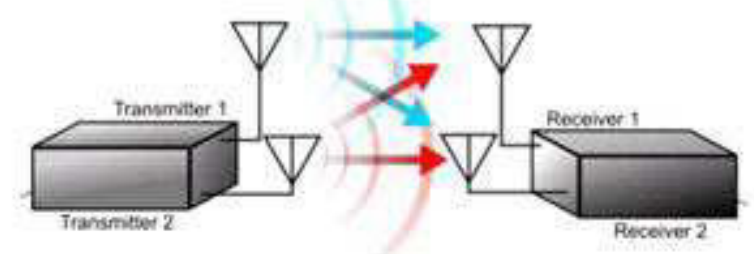

Figura 2.4: Sistema MIMO

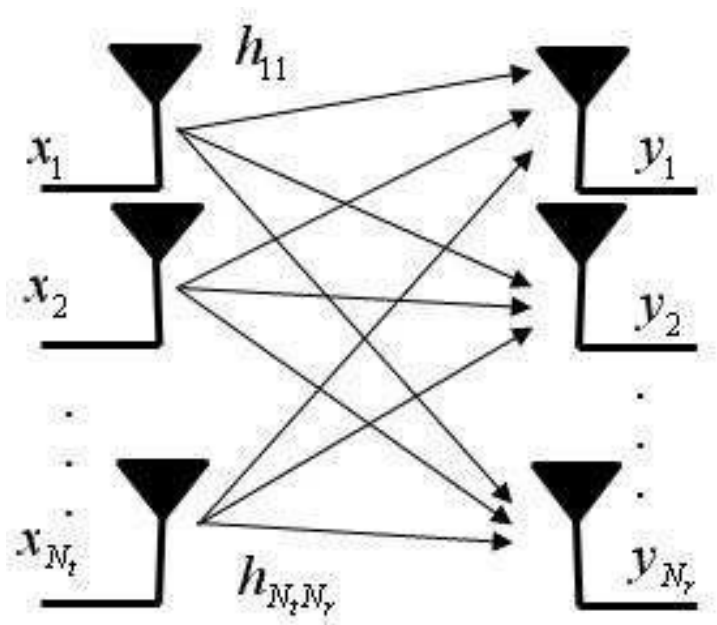

Figura 2.5: Modelo do canal no sistema MIMO

ou simplesmente:

$$
y=\mathbf{H} x+n
$$

$$
\left[\begin{array}{c}
y_{1} \\
\vdots \\
y_{N_{r}}
\end{array}\right]=\left[\begin{array}{ccc}
h_{11} & \cdots & h_{1 N_{t}} \\
\vdots & \ddots & \vdots \\
h_{N_{r} 1} & \cdots & h_{N_{r} N_{t}}
\end{array}\right]\left[\begin{array}{c}
x_{1} \\
\vdots \\
x_{N_{t}}
\end{array}\right]+\left[\begin{array}{c}
n_{1} \\
\vdots \\
n_{N_{r}}
\end{array}\right]
$$

Figura 2.6: Matriz do canal no sistema MIMO

Sendo o tamanho do vetor recebido $y$ igual a $N_{r} x 1$, a matriz do canal $\mathbf{H}$ é $N_{r} x N_{t}$, o vetor transmitido $x$ é $N_{t} x 1$. Tipicamente, o vetor de transmissão é normalizado por $N_{t}$, de modo que cada símbolo em $x$ tenha a energia média 
$\varepsilon_{x} / N_{t}$. Isto mantém a energia total transmitida constante, se comparado com o caso SISO, $h_{i j}$ representa o ganho da antena transmissora $j$ relativo ao da antena receptora $i$.

Dado um limite de potência $\mathrm{P}$, é assumido um modelo equivalente com uma potência de ruído $\sigma^{2}$ e uma potência de transmissão $P / \sigma^{2}=\rho$, onde $\rho$ pode se interpretar como a SNR média por antena receptora, sob um ganho de canal unitário. Isto implica que a entrada de símbolos satisfaz à equação 2-2

$$
\sum_{i=1}^{N_{t}} E\left[x_{i} x_{i}^{H}\right]=\rho
$$

ou (equivalente) $\operatorname{Tr}\left(R_{x}\right)=\rho$, onde $\operatorname{Tr}\left(R_{x}\right)$ é o trazo da matriz de covariância da entrada $R_{x}=E\left[x x^{H}\right]$.

Diferentes hipóteses podem ser feitas acerca do conhecimento da matriz de ganho de canal $\mathbf{H}$ no transmissor e receptor, referida como informações de canal lateral no transmissor (CSIT) e informações de canal lateral para o receptor (CSIR), respectivamente. Para um canal estático CSIR é normalmente assumido, uma vez que os ganhos de canal podem ser facilmente obtidos através do envio de uma sequência piloto para a estimativa do canal [3]

Segundo Telatar [4], são considerados diferentes cenários para a matriz $\mathbf{H}$ :

- H é determinística.

- H é uma matriz aleatória (é por isso que a notação é $\mathbf{H}$, mas não H), escolhida de acordo com a distribuição de probabilidade, e cada uso do canal corresponde a uma realização independente do $\mathbf{H}$.

- H é uma matriz aleatória, mais fixa, uma vez que é escolhida.

No caso em que $\mathbf{H}$ seja aleatório, é assumido que as entradas geram uma coleção de sinais estatisticamente independentes com média zero e com partes reais e imaginárias independentes, cada uma com variância igual a 1/2. Equivalentemente, cada entrada de $\mathbf{H}$ tem fase uniforme e magnitude Rayleigh. Em todo caso, assume se a realização de $\mathbf{H}$ é conhecida no receptor. 


\section{5}

\section{Conclusões}

Neste capítulo é realizado o estudo dos sistemas MIMO, que têm como principal característica a diversidade em espaço, devido ao aumento no número de antenas na transmissão e recepção, e a multiplexação espacial pela divisão dos pacotes enviados de forma independente a cada uma das antenas de transmissão.

MIMO e Smart Antennas podem ser facilmente confundidas, pois são sistemas de multiplas antenas. A diferença aparece no sistema de multiplexação utilizado nos sistemas MIMO.

A caracterização do canal é realizada e a matriz do canal é definida e conhecida na recepção. 


\section{3 \\ Desvanecimento}

O sinal de propagação sofre alterações no caminho até chegar ao receptor que levam à atenuação do mesmo. Dependendo da característica do canal, existem diferentes tipos de desvanecimento. Este capítulo apresenta os fenómenos encontrados de desvanecimento, além das técnicas de mitigação utilizadas de forma a melhorar o desempenho do sistema.

\section{1 \\ Desvanecimento em larga escala}

Pode se dizer que este tipo de desvanecimento ocorre em escala humana, pois o tempo em que acontece é em dezenas de segundo no movimento de alguns metros. Encontramos reflexão, difração ou espalhamento do sinal dependendo do tipo de obstáculo no qual percorram, o que comunmente são morros, montanhas, etc., que podem gerar uma perda do sinal. Tecnicamente, o desvanecimento em larga escala representa uma média da atenuação da potência do sinal em grandes áreas. É possível evitar esse tipo de desvanecimento se esquivando das obstruções, adicionando mais de uma estação base e o sinal terá, pelo menos, uma opção de curso onde não irá sofrer obstrução.

\section{2}

\section{Desvanecimento em pequena escala}

É chamado assim devido às variações que acontecem em uma escala muito menor, pois o sinal varia rapidamente em pouco tempo, não em segundos mas em milissegundos. Neste tipo de desvanecimento existem dois efeitos diferentes: Seletividade em Frequência e no Tempo. A Seletividade em Frequência é produzida por uma multiplicidade de raios que chegam ao receptor tendo percorrido diferentes distâncias e, por conseguinte, em diferentes tempos; a Seletividade no Tempo ou Efeito Doppler, é a mudança 
de frequência de uma onda produzida pelo movimento relativo da fonte em relação ao observador.[5]

\section{3}

\section{Mitigação do desvanecimento}

Em um canal de comunicação sem fio são necessários certos requisitos como alta qualidade de voz, altas velocidades de dados, dispositivos cada vez mais leves, entre outros; mas no mundo real aquelas características não são ideais, pois invariâncias climáticas do planeta geram aleatoriedade no canal, reduzindo a qualidade da comunicação, incluindo o efeito de vários caminhos de propagação.

O fenômeno de múltiplos caminhos (multipath) ocorre nos canais sem fios por causa dos ambientes físicos que, tipicamente, têm objetos que difratam ou dispersam as ondas de rádio. Uma vez que são alteradas as frentes de onda dos sinais, haverá múltiplas vias onde a energia eletromagnética pode se propagar através do caminho do emissor para o receptor e cada cópia do sinal sofrerá atenuação, distorções, atrasos ou mudanças de fase, por conseguinte, é necessário reduzir o problema do desvanecimento, mas não à custa da largura de banda adicional.

Um método útil é a diversidade, usado em comunicações sem fio para melhorar o desempenho em um canal rádio com desvanecimento. Nesta técnica, o receptor obtém múltiplas cópias do sinal de informação que é transmitida por dois ou mais canais de comunicação virtuais ou reais, tendo como idéia principal a redundância de informação.

\section{4}

\section{Tipos de Diversidade}

\subsection{1}

\section{Diversidade Microscópica}

A diversidade microscópica é usada em ambientes com desvanecimento de pequena escala. A mudança rápida do sinal é aproveitada para evitar 
profundos desvanecimentos. No caso de desvanecimento em pequena escala é conhecido que, se as duas antenas estão separados por uma fração de um metro, uma delas pode receber um zero, enquanto a outra recebe um sinal forte. Selecionando o melhor sinal em cada tempo, um receptor pode mitigar os efeitos do desvanecimento [5].

\section{4 .2}

\section{Diversidade Macroscópica}

A diversidade macroscópica é utilizada para combinar dois ou mais sinais sujeitos a desvanecimento em larga escala, que são obtidos através de percursos de desvanecimento independentes recebidos de duas ou mais antenas de estações rádio base diferentes.

\section{5}

\section{Técnicas de Diversidade}

Principalmente há cinco técnicas de diversidade, destacadas nos itens seguintes.

\subsection{1}

\section{Diversidade de frequência}

O mesmo sinal de informação é transmitido em diferentes portadoras e a separação de frequências entre elas deve ser, pelo menos, a largura de banda de coerência do canal. A figura 3.1 apresenta o diagrama $t x f$ que relaciona tempo com frequência para exemplificar duas portadoras espaçadas de $\Delta f$.

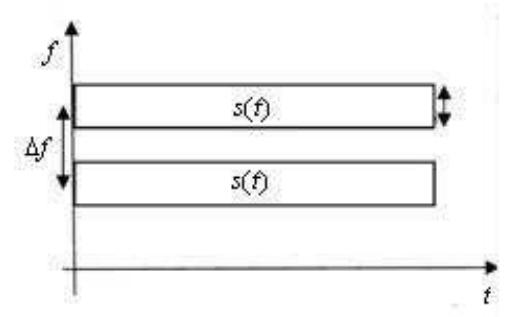

Figura 3.1: Diversidade em Frequência 


\subsection{2}

\section{Diversidade de Tempo}

O sinal de informação é transmitido ao longo do tempo, repetidamente em intervalos regulares. A separação entre os tempos de transmissão deve ser maior do que o tempo de coerência. O intervalo de tempo $\Delta t$ depende da taxa de desvanecimento e aumenta com a diminuição da taxa de desvanecimento. A figura 3.2 ilustra a diversidade no tempo para exemplificar dois sinais espaçados de $\Delta t$.

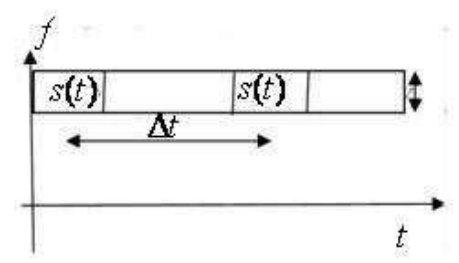

Figura 3.2: Diversidade no Tempo

\subsection{3 \\ Diversidade de Polarização}

Os campos elétricos e magnéticos do sinal carregando a informação são alterados e muitos sinais são usados para enviar a mesma informação, de modo que o tipo de polarização ortogonal é obtido. A vantagem deste tipo de polarização com respeito à diversidade em espaço é o ganho de diversidade que é possível com antenas co-localizadas.

\subsection{4}

\section{Diversidade de Ângulo}

Este tipo de diversidade pode ser aplicado à estação de base ou na unidade móvel. Na estação de base tem-se:

\section{- Diversidade angular de tempo}

Combinam os dois sinais recebidos, simultaneamente para atingir o ganho da diversidade. Esta é uma diversidade microscópica. 


\section{- Diversidade angular fora do tempo}

A intensidade de cada feixe do sinal da unidade móvel é monitorada constantemente na estação base do sistema multi-feixe da antena. O feixe mais forte é usado pela ligação de tráfego.

Na unidade móvel tem-se:

Se o sinal recebido atinge a antena por vários caminhos, cada um com um ângulo diferente de chegada, as componentes do sinal podem ser isoladas por meio de antenas diretivas. Cada antena diretiva isolará uma componente angular diferente e os sinais recebidos a partir de diferentes antenas sao descorrelatados.

\subsection{5}

\section{Diversidade de Espaço}

Há múltiplas antenas de recepção localizadas em diferentes posições espaciais, resultando em diferentes sinais recebidos (possivelmente independentes).

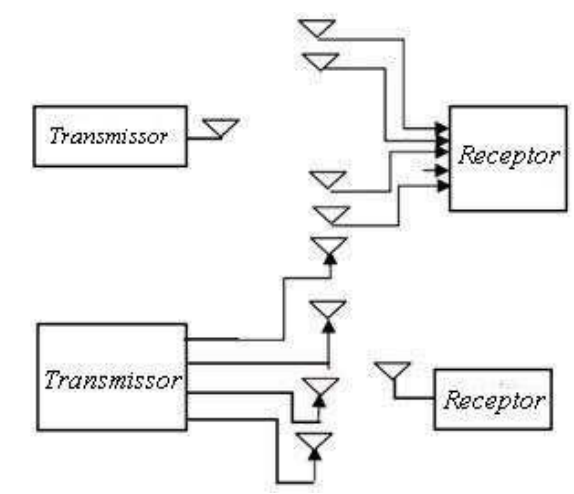

Figura 3.3: Diversidade de Espaço

\section{- Diversidade de escolha}

M moduladores são usados para fornecer $m$ diversos ramos cujos ganhos são ajustados para fornecer igual relação sinal-ruído. O ramo receptor tendo a relação sinal-ruído instantânea superior é ligado ao demodulador. 


\section{- Diversidade de realimentação ou de varredura}

Semelhante ao anterior, entretanto todos os M sinais são digitalizados em uma sequência fixa até que uma delas fique acima do limite predeterminado. Esse sinal é recebido até que a potência caia abaixo do limiar e o processo de digitalização seja iniciado novamente.

\section{- Combinação de Máxima Taxa}

Todos os sinais de entrada dos $M$ ramos são ponderados de acordo com a tensão de sinal individual à razão da potência de ruído e, em seguida, somados. Os sinais devem ter a mesma fase antes de serem somados. Isso requer $n$ circuitos de recepção individuais e circuitos de correção de fase para cada elemento de antenas. Esta técnica de Combinação de Máxima Taxa produz uma relação sinal ruído aceitável em comparação com outras técnicas.

\section{- Combinação Ganho Igual}

Neste caso, os pesos de cada ramo são todos unitários, mas os sinais de cada ramo posuem a mesma fase para fornecer igual ganho de combinação. Isso permite que o receptor aproveite os sinais recebidos, simultaneamente, em todos os ramos. [6]

O ganho de diversidade é, tipicamente, expresso em termos de ordem de diversidade, que pode se referir tanto ao número de ramos de diversidade efetivamente independentes ou à inclinação da curva da taxa de erro de bit (BER) em função da razão sinal-ruído. A ordem máxima de diversidade que um sistema é capaz de atingir sob certas condições do canal é $N_{t} N_{r}$ [7].

\section{6}

\section{Ambiente multipercurso}

Em um ambiente multipercurso, é razoavelmente intuitivo visualizar que um impulso transmitido pelo transmissor vai chegar ao receptor como um trem de impulsos. A figura 3.4 apresenta a resposta ao impulso de um canal multipercurso

O sinal passabanda transmitido $x(t)$ é apresentado na equação 3-1:

$$
x(t)=\Re\left\{x_{b}(t) e^{j 2 \pi f_{c} t}\right\}
$$


Transmissor

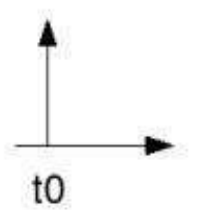

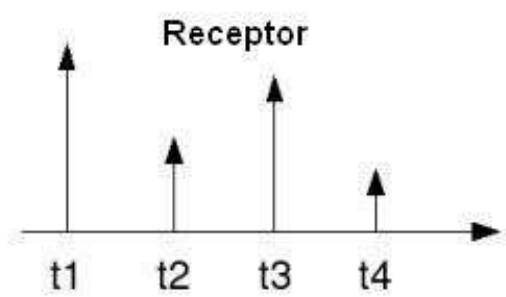

$\begin{array}{llll}t 1 & t 2 & t 3 & t 4\end{array}$

Figura 3.4: Resposta ao impulso de um canal multipercurso

onde $x_{b}(t)$ é o sinal em banda base, $f_{c}$ é a frequência de portadora, $t$ é o tempo.

Como foi apresentado, o sinal de transmissão chega ao receptor por meio de vários caminhos onde o n-ésimo caminho tem uma atenuaçaõ $\alpha(t)$ e um atraso $\tau_{n}(t)$. O sinal recebido $y(t)$ é formulado de acordo com a equação 3-2:

$$
y(t)=\Re\left\{\sum_{n} \alpha_{n}(t) x_{b}\left[t-\tau_{n}(t)\right] e^{j 2 \pi f_{c}\left[t-\tau_{n}(t)\right]}\right\}
$$

O equivalente em bandabase do sinal recebido, $y_{b}(t)$, é formulado pela equação 3-3:

$$
y_{b}(t)=\sum_{n} \alpha_{n}(t) e^{-j 2 \pi f_{c} \tau_{n}(t)} x_{b}\left[t-\tau_{n}(t)\right]=\sum_{n} \alpha_{n}(t) e^{-j \theta_{n}(t)} x_{b}\left[t-\tau_{n}(t)\right]
$$

Onde $\theta_{n}(t)=2 \pi f_{c} \tau_{n}(t)$ é a fase do n-ésimo caminho.

A resposta ao impulso $h_{b}(t)$ então é descrita pela equação 3-4:

$$
h_{b}(t)=\sum_{n} \alpha_{n}(t) e^{-j \theta_{n}(t)}
$$

\section{7}

\section{Canal de desvanecimento plano tipo Rayleigh}

A fase de cada caminho pode mudar a cada $2 \pi$ radianos quando o atraso $\tau_{n}(t)$ muda de $1 / f_{c}$. Se $f_{c}$ é grande, os pequenos movimentos relati- 
vos no meio podem causar mudança de radianos. Uma vez que a distância entre os dispositivos são muito maiores do que o comprimento de onda da frequência da portadora, é possível assumir que a fase é uniformemente distribuída entre 0 e $2 \pi$ radianos e as fases de cada caminho são independentes.

O canal rádio-móvel plano em frequência é representativo do cenário onde a banda de coerência do canal é significativamente maior que a largura de faixa do sinal transmitido [8].

Quando há um grande número de caminhos e aplicando o Teorema do Limite Central, cada caminho pode ser modelado como uma variável aleatória Gaussiana complexa circularmente simétrica com o tempo como a variável. Este modelo é o modelo de canal de desvanecimento Rayleigh.

Uma variável aleatória Gaussiana complexa circularmente simétrica $Z$ tem a forma:

$$
Z=X+j Y
$$

As partes reais e imaginárias são variáveis aleatórias Gaussianas independentes e identicamente distribuídas (iid) com média zero. Para uma variável aleatória complexa circularmente simétrica $Z$, a média $E(Z)$ é expressa pela equação 3-6 :

$$
E[Z]=E\left[e^{j \theta} Z\right]=e^{j \theta} E[Z]
$$

A estatística de uma variável aleatória Gaussiana complexa circularmente simétrica é completamente especificada pela variância apresentada na equação 3-7 :

$$
\sigma^{2}=E\left[Z^{2}\right]
$$

A magnitude $|Z|$, à qual tem uma densidade de probabilidade $p(z)$, é dada pela equação 3-8, e é chamada uma variável aleatória Gaussiana.[17][9]

$$
p(z)=\frac{z}{\sigma^{2}} e^{\frac{-z^{2}}{2 \sigma^{2}}}, z \geq 0
$$


O sinal recebido $y$ é resultado da formulação 3-9:

$$
\begin{gathered}
y=\mathbf{H}(t) x(t)+n(t) \\
=x(t) \beta(t) e^{j \theta(t)}+n(t)
\end{gathered}
$$

onde $\mathrm{x}(\mathrm{t})$ é o sinal transmitido, $\mathbf{H}(\mathrm{t})$ representa as variações temporais da resposta em frequência do canal e $\mathrm{n}(\mathrm{t})$ é a componente de ruído aditivo. Sendo complexa, $\mathbf{H}(\mathrm{t})$ contempla a magnitude do desvanecimento e as rotações de fase introduzidas pelo canal. Por exemplo, para simulação do canal Rayleigh plano, basta multiplicar o sinal transmitido pelo processo aleatório Gaussiano complexo $\beta(t) e^{j \theta(t)}$, onde $\beta(t)$ é um processo aleatório com distribuição Rayleigh e $\theta(t)$ é um processo aleatório com distribuição uniforme em $[0,2 \pi]$.

Para o sinal modulado, um canal plano equivale a um canal com um único percurso de propagação, mesmo que mais de um percurso realmente exista. Neste último caso as contribuições dos vários percursos se somam no lado da recepção, ou seja, os percursos não são "discrimináveis".[8]

\section{8 \\ Conclusões}

O Desvanecimento é um fenômeno comum nos sistemas sem fio, sendo parte importante no projeto do sistema. Nos sistemas MIMO, a técnica de combate ao desvanecimento mais utilizada é a diversidade em espaço, onde com ajuda do número de antenas empregadas mitiga o efeito canal no sinal. Este capítulo apresenta o modelo do canal Rayleigh utilizado nos próximos capítulos para a simulação e teste do sistema MIMO de desvanecimento plano. 


\section{4}

\section{Sistema MIMO 2x2}

Ao longo do presente capítulo o sistema básico MIMO será introduzido, mostrando o diagrama de blocos do transmissor, receptor e canal modelados para o desenvolvimento do setup.

\section{1}

\section{Transmissor}

O sistema básico do transmissor é apresentado na figura 4.1. Ele foi feito para um sistema MIMO 2x2, o qual é formado por un gerador de bits pseudoaleatório.

Depois do gerador o sinal é formatado no sistema para se agrupar em palavras de dois bits. Cabe ressaltar que o comprimento da palavra é ajustado de forma que o transmissor vai enviar um bit por antena transmissora, portanto, um demultiplexador deve ser adicionado para dividir os streams de igual tamanho a cada saída.

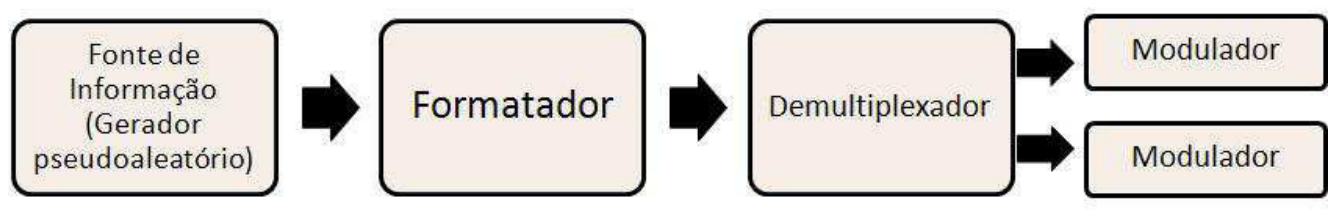

Figura 4.1: Transmissor para o sistema MIMO

\subsection{1}

\section{Multiplexação Espacial}

Trata-se de um tipo especial de multiplexação onde diferentes sinais ou bits de dados são transmitidos através de diferentes canais de comunicação 
independentes por múltiplas antenas e, simultaneamente, o lado de recepção também usa várias antenas para os sinais recebidos, assim aumentando a taxa de transmissão de dados que está em proporção direta com o número de antenas usadas para fins de transmissão e recepção. Quanto maior for o número de antenas, maior é a taxa de transmissão de dados. É uma técnica patenteada de multiplexação desenvolvida pela Universidade de Stanford. Não requerimentos adicionais de potência ou de largura de banda estão entre seus beneficios. A figura 4.2 ilustra a técnica de multiplexação espacial empregada entre o transmissor $(\mathrm{Tx})$ e o receptor $(\mathrm{Rx})$.

Essa técnica leva vantagem no grau extra de liberdade proveniente dos caminhos espaciais independentes para o envio de streams de informação simultaneamente, nas mesmas frequências [11]

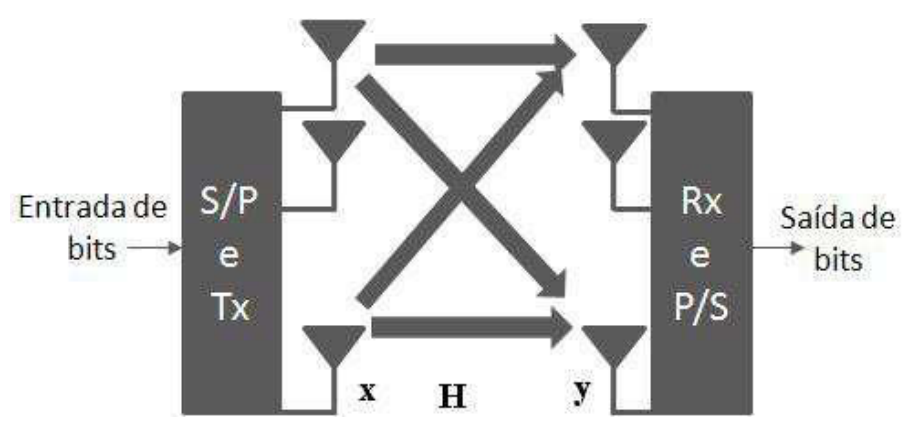

Figura 4.2: Multiplexação Espacial

Na multiplexação espacial um stream de alta taxa de transmissão é quebrado em $N_{t}$ streams independentes, como na figura 4.2. Supondo que os strems ou fluxo de dados podem ser decodificados com sucesso, a eficiência nominal espectral é, então incrementada por um fator de $N_{t}$. Isso implica que, adicionando-se antenas, pode-se aumentar a viabilidade das altas taxas de dados desejados para o acesso a internet de banda larga sem fio.

O modelo para multiplexação espacial é a equação 2-1. A matriz de canal $\mathbf{H}$ tem a forma:

$$
\mathbf{H}=\left[\begin{array}{cccc}
h_{11} & h_{12} & \cdots & h_{1 N_{t}} \\
h_{21} & h_{22} & \cdots & h_{2 N_{t}} \\
\vdots & \vdots & \ddots & \vdots \\
h_{N_{r} 1} & h_{N_{r} 2} & \cdots & h_{N_{r} N_{t}}
\end{array}\right]
$$


É geralmente assumido que as entradas da matriz de canal e o vetor de ruído são Gaussianas complexas e i.i.d com média zero e matriz de covariância que podem ser escritas como $\sigma_{h}^{2} \mathbf{I}$ e $\sigma_{z}^{2} \mathbf{I}$, respectivamente. É simples confirmar que decodificando $N_{t}$ streams é teoricamente possível quando existe, pelo menos, $N_{t}$ autovalores diferentes de zero na matriz de canal, isto é $\operatorname{rank}(\mathbf{H}) \geq N_{t}$

Assim, os principais pontos abordados em um enlace MIMO simples, são:

- A capacidade ou taxa máxima de dados aumenta à medida que $\min \left(N_{t}, N_{r}\right) \log (1+S N R)$ aumenta, quando a SNR é alta. Assim, a multiplexação espacial é ótima.

- Quando a SNR é baixa, a estratégia de maximização da capacidade é enviar um único stream de dados usando precodificação de diversidade. Embora seja muito menor do que em uma SNR alta, a capacidade ainda cresce aproximadamente linear com o $\min \left(N_{t}, N_{r}\right)$, uma vez que a capacidade é linear com a SNR no regime de baixa SNR.

- Ambos os casos são superiores em termos de capacidade para a codificação espaço/tempo, no qual a taxa de dados cresce logaritmicamente com o $N_{r}$.

\section{Multiplexação Espacial Sem Retroalimentação do Canal}

(Open Loop MIMO) Neste tipo de multiplexação espacial não é usada a informação do canal. Tenta-se remover a interferência resultante de todos os $N_{t}$ fluxos recebidos por cada uma das $N_{r}$ antenas.

\section{Multiplexação Espacial com Retroalimentação do Canal}

(Closed-Loop MIMO) O ganho potencial de um transmissor com conhecimento do canal é significativo nos sistemas de multiplexação espacial. 


\section{Precodificação e Poscodificação com decomposição em Valores Singulares (SVD)}

Esta é uma forma simples de ver o ganho do transmissor com conhecimento do canal onde se faz a decomposição de autovalores generalizados da matriz do canal $\mathbf{H}$ [13]. Partindo da equação 2-1, assume-se que a matriz do canal é determinística e é constante em todos os momentos, além de conhecida no transmissor e receptor. Este é um vetor de canal Gaussiano e a capacidade pode ser calculada pela decomposição do vetor canal em subcanais gaussianos estelares, independentes e paralelos. Cada transformação linear pode ser representada como uma composição de três operações: rotação, ampliação e mais outra rotação. Em notação matricial o canal $(\mathbf{H})$ pode ser escrito pela equação 4-2.

$$
\mathbf{H}=\mathbf{U} \Lambda \mathbf{V}^{H}
$$

onde $\mathbf{U}$ e $\mathbf{V}$ são unitários e $\Lambda$ é a matriz diagonal de valores unitários [17].

A figura 4.3 ilustra o proceso SVD (decomposição em valores singulares).

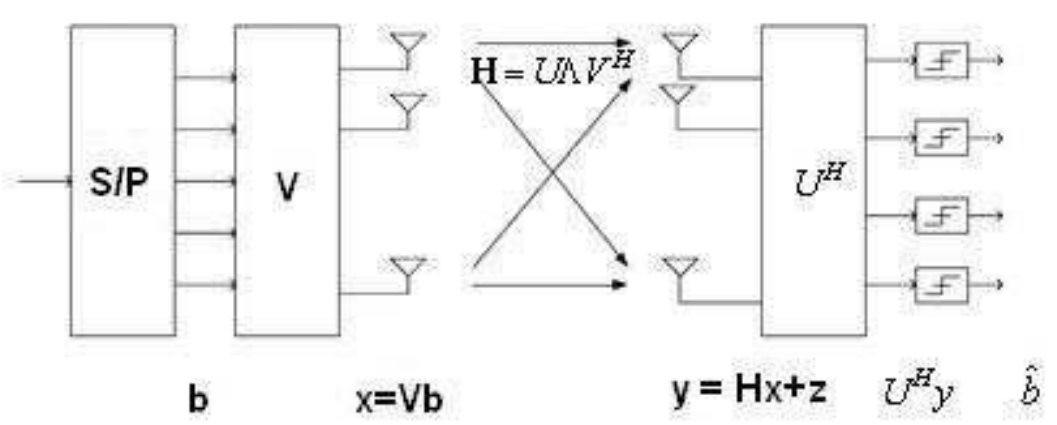

Figura 4.3: Processo do SVD

Com operações lineares no transmissor e receptor que são multiplicados, respectivamente, por $\mathbf{V}$ e $\mathbf{U}^{H}$, o canal pode ser diagonalizado. Matematicamente, isto pode ser confirmado considerando um vetor de decisão que deve ser próximo ao vetor símbolo de entrada b. O vetor de decisão $(d)$ pode ser escrito, sistematicamente, como a equação ??: 


$$
\begin{aligned}
d & =\mathbf{U}^{H} y \\
& =\mathbf{U}^{H}(\mathbf{H} x+n) \\
& =\mathbf{U}^{H}\left(\mathbf{U} \Lambda \mathbf{V}^{H} \mathbf{V} b+n\right) \\
& =\mathbf{U}^{H} \mathbf{U} \Lambda \mathbf{V}^{H} \mathbf{V} b+\mathbf{U}^{H} n \\
& =\Lambda b+\mathbf{U}^{H} n
\end{aligned}
$$

o que diagonalizou o canal e removeu toda a interferência espacial sem inversões de matriz ou processamento não linear. Como $\mathbf{U}$ é unitária, $\mathbf{U}^{n}$ tem a mesma variância que $\mathrm{n}$, de modo a que não há nenhuma melhoria de ruído como na técnica sem retroalimentação. [3][13]

\section{Precodificação e Poscodificação Linear}

Com o processo SVD foi demonstrado como se pode diagonalizar a matriz do canal MIMO para fornecer até $\min \left(N_{r}, N_{t}\right)$ dimensões para comunicar os símbolos de dados. Com a precodificação linear, o vetor recebido de dados $y$ pode ser escrito pela equação 4-3.

$$
y=\mathbf{G}(\mathbf{H F} x+n)
$$

onde os tamanhos dos vetores de símbolo transmitido $x$ e recebidos $y$ são $M x 1$, a matriz do poscodificador $\mathrm{G}$ é $M x N_{r}$, a matriz do canal $\mathbf{H}$ é $N_{r} x N_{t}$, a matriz do precodificador $\mathbf{F}$ é $N_{t} x M$ e o vetor de ruído $n$ é $N_{r} x 1, M=\min \left(N_{r}, N_{t}\right), \mathbf{G}=\mathbf{U}^{H}$ e $\mathbf{F}=\mathbf{V}$.

Independentemente dos critérios do projeto, o precodificador e poscodificador linear decompõem o canal MIMO em um conjunto de sub-canais paralelos como ilustra a figura 4.4, portanto, o símbolo recebido para o i-ésimo subcanal $y_{i}$ pode ser expresso como:

$$
y_{i}=\alpha_{i} \sigma_{i} \beta_{i} x_{i}+\beta_{i} n_{i}, i=1, \ldots M
$$

onde $x_{i}$ e $y_{i}$ são os símbolos transmitidos e recebidos com $E\left|x_{i}\right|^{2}=\varepsilon_{x} \sigma_{i}$ sendo os valores únicos de $\mathbf{H}, \alpha_{i}$ e $\beta_{i}$ são os pesos (weights) do precodificador e poscodificador, respectivamente. Através dos pesos do precodificador, pode-se maximizar a capacidade total distribuindo mais potência de transmissão aos 


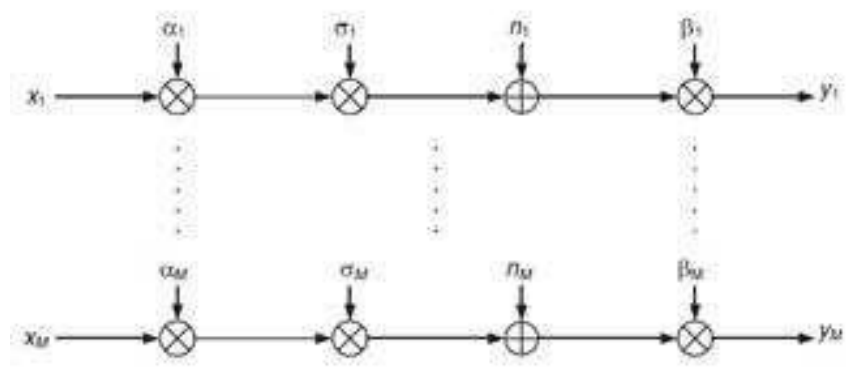

Figura 4.4: Subcanais paralelos

subcanais com ganhos maiores e menos aos outros (waterfilling).

O número de subcanais está limitado por:

$$
1 \leq M \leq \min \left(N_{t}, N_{r}\right)
$$

onde $M=1$, é a ordem de máxima diversidade, chamada precodificação de diversidade e $M=\min \left(N_{t}, N_{r}\right)$ atinge o número máximo de fluxos paralelos espaciais.

Com ajuda de um demultiplexador, poderá ser feito o processo de multiplexação espacial, que fará a divisão dos streams em partes iguais dependendo do número de saídas a utilizar (antenas), portanto, ele é um distribuidor de dados que aceita uma entrada de dados e seleciona entre várias, a saída para receber os dados de entrada, controlado por um código de entradas de seleção. Desta forma, o demultiplexador recebe uma fonte de entrada de dados e, seletivamente, os distribui para 1 entre $N$ canais de saida.

\subsection{2}

\section{Modulação}

O tipo de modulação empregado é BPSK (Binary Phase Shift Keying), Seu objetivo é modular um sinal analógico com uma sequência digital para transportar essa sequência sobre um meio dado que, neste casso, é um enlace de RF. 
A modulação BPSK é suportada pelo padrão IEEE 802.16. É uma modulação digital binária, o que dá uma alta immunidade contra ruído e interferência além de uma modulação robusta. Uma modulação em fase (o caso da modulação BPSK) usa a variação de fase para codificar bits: cada símbolo de modulação é equivalente a uma fase. A fase do sinal modulado em BPSK é $\pi$ ou $-\pi$ de acordo com o valor do bit de informação [12]. A figura 4.5 ilustra a constelação BPSK descrita.

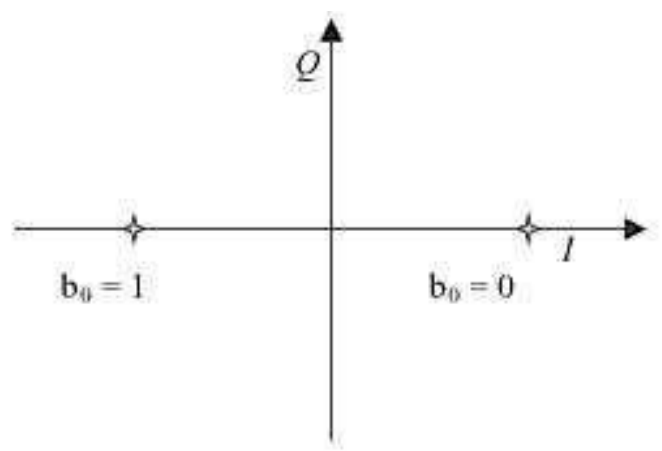

Figura 4.5: Constelação BPSK

\section{2 \\ Receptor}

No caso do receptor, como o sistema é MIMO 2x2, vai ter duas entradas de sinal, que passam por um equalizador, ajuda a eliminar as interferências do canal e o ruido próprio dos receptores, em seguida um decisor e um multiplexador é utilizado para a recepção adequada do sinal transmitido.

\subsection{1}

\section{Decodificação Ótima : Máxima probabilidade de Detecção (ML detection)}

Se o transmisor desconhece o canal, um decodificador ótimo seria o Maximum-likelihood-decoder (ML), que encontra a entrada do vetor $x$ mais provável por meio de um circuito de mínima distância:

$$
\hat{x}=\arg \min \|y-\mathbf{H} \hat{x}\|^{2}
$$




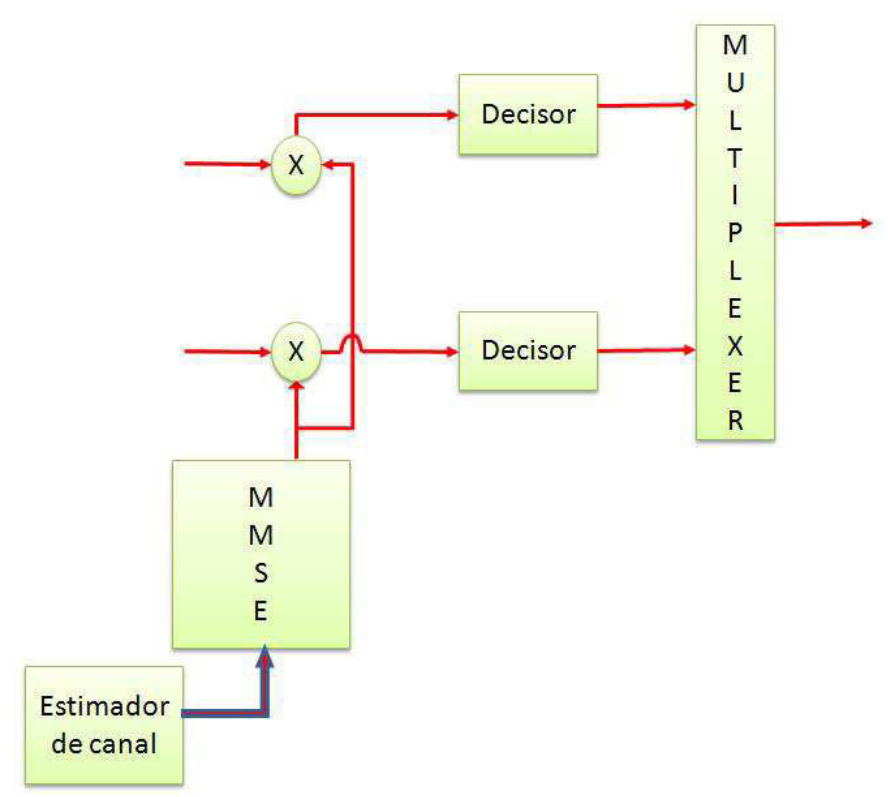

Figura 4.6: Receptor para o sistema MIMO

onde $x$ representa o símbolo de espaço-tempo, $\mathbf{H}$ é a matriz do canal e $y$ é o vetor do sinal recebido.

Infelizmente, não há maneira simples de calcular a entrada do vetor $x$ mais provãvel e, por conseguinte, uma pesquisa exaustiva deve ser feita em todos os $M^{N_{t}}$ vetores possíveis de entrada, onde $M$ é a ordem de modulação (por exemplo, QPSK $M=4$ )[13].

\subsection{2}

\section{Detetores lineares}

São baseados na multiplicação pelo inverso da matriz de canal para reconstruir o sinal transmitido [14], e suprimir a interferência de outros símbolos transmitidos. O detector deste tipo mais comum é chamado Zero Forcing que coloca o receptor igual ao inverso do canal $\mathbf{G}_{z f}=\mathbf{H}^{-1}$, quando $N_{t}=N_{r}$ ou, mais geralmente para a pseudoinversa:

$$
\begin{gathered}
\mathbf{G}_{z f}=\left(\mathbf{H}^{H} \mathbf{H}\right)^{-1} \mathbf{H}^{H} \\
\hat{x}=\mathbf{G}_{z f} y=\mathbf{G}_{z f} \mathbf{H} x+\mathbf{G}_{z f} n=x+\left(\mathbf{H}^{H} \mathbf{H}\right)^{-1} \mathbf{H}^{H} n
\end{gathered}
$$


onde $\mathbf{H}^{H}$ é a conjugada transposta da matriz do canal, $\hat{x}$ é o vetor estimado do sinal transmitido, $y$ é o sinal recebido e $n$ é o vetor de ruido nos receptores.

Como $\mathbf{G}_{z f}$ inverte os autovalores de $\mathbf{H}$, subcanais espaciais mais ruins podem severamente amplificar o ruído em $n$. Isto é particularmente problemático em sistemas MIMO de interferência limitada, resultando em um desempenho extremamente pobre, portanto, não é prático em algumas tecnologias como o WIMAX.

\subsection{3}

\section{Detetor Linear do Mínimo Erro Quadrático Médio (MMSE)}

A detecção linear pode ser melhorada usando o critério do erro médio quadratico mínimo , o que minimiza o erro total devido à combinação de ruído e distorção [14]. O detetor de Zero-Forcing elimina a interferência, mas aumenta o ruído. Isto pode não ser significativo para uma alta SNR, mas piora em SNR baixos [15], por isso o equalizador MMSE será utilizado em nosso sistema MIMO, devido a vantagem frente ao detetor Zero Forcing e a simplicidade comparada com o detetor ML. E, portanto, um método que minimiza o erro quadrático médio (MSE), que é uma medida comum da qualidade do estimador. $O$ equalizador não elimina completamente a interferência entre símbolos, mas em vez disto, minimiza a potência total de ruído e as componentes da interferência intersimbólica na saída.

$$
\mathbf{G}_{m m s e}=\arg \min E\|\mathbf{G} y-x\|^{2}
$$

Tendo o sinal do sistema MIMO da equação 2-1, pode se dizer que o detector MMSE fica:

$$
\mathbf{G}_{m m s e}=R_{y}^{-1} E\left[y x^{H}\right]
$$


Onde

$$
\begin{aligned}
R_{y}=E\left[y y^{H}\right] & =E\left[(\mathbf{H} x+n)(\mathbf{H} x+n)^{H}\right] \\
& =E\left[(\mathbf{H} x+n)\left(\mathbf{H}^{H} x^{H}+n^{H}\right]\right. \\
& =E\left[\mathbf{H} x x^{H} \mathbf{H}^{H}+\mathbf{H} x n^{H}+n \mathbf{H}^{H} x+n n^{H}\right] \\
& =\mathbf{H} E\left[x x^{H}\right] \mathbf{H}^{H}+E\left[n n^{H}\right]
\end{aligned}
$$

Observações

- H e n são estatisticamente independentes.

- $E\left[x x^{H}\right]=1$

- $n$ é um ruído gaussiano ou branco de media nula $(E[n]=0)$ e matriz de autocorrelaçaõ $\sigma^{2} \mathbf{I}$, onde $I$ é a matriz identidade e $\sigma^{2}$ é a variância do ruido branco Gaussiano.

$$
\begin{aligned}
R_{y} & =\mathbf{H H}^{H}+\sigma^{2} \mathbf{I} \\
R_{y}^{-1} & =\left(\mathbf{H H}^{H}+\sigma^{2} \mathbf{I}\right)^{-1}
\end{aligned}
$$

Pelo que:

$$
\begin{aligned}
E\left[y x^{H}\right] & =E\left[(\mathbf{H} x+n) x^{H}\right] \\
& =E\left[\mathbf{H} x x^{H}\right]+E\left[n x^{H}\right] \\
& =\mathbf{H} E\left[x x^{H}\right]+E[n] E\left[x^{H}\right] \\
& =\mathbf{H} E\left[x x^{H}\right]+0 \\
& =\mathbf{H}
\end{aligned}
$$

Finalmente, de acordo com [16]:

$$
\mathbf{G}_{m m s e}=\left(\mathbf{H H}^{H}+N_{t} \sigma^{2} \mathbf{I}\right)^{-1} \mathbf{H}^{H}
$$

Tendo $\mathbf{G}$ obtemos $\hat{x}$ [13]:

$$
\hat{x}=\mathbf{G}_{m m s e} y
$$


O canal estimado é do tipo Rayleigh, como foi explicado no capítulo 3 , então os valores da matriz do canal serão inseridos no equalizador MMSE para fazer o processo de eliminação de interferências e ruído adicionado aos símbolos enviados.

Terminada a equalização, os símbolos vão passar por um decisor, que é um detetor de limiar, que dependendo dos valores de tensão positivo ou negativos vai decidir se o bit final é um 0 ou 1 lógico. Assim, os bits recebidos são organizados pelo multiplexador, que fará a função contrária do demultiplexador.

\section{3}

\section{Capacidade MIMO}

A capacidade do canal depende do conhecido na matriz de ganho do canal ou da sua distribuição no transmissor ou no receptor.

A partir de uma extensão da fórmula de informação mútua para um determinado canal SISO a capacidade para uma matriz de canal é expressa pela equação 4-11:

$$
C=\max _{p(x)} I(X ; Y)=\max _{p(x)} \sum_{x, y} p(x, y) \log \frac{p(x, y)}{p(x) p(y)}
$$

Para um canal estático, uma boa estimativa de $\mathbf{H}$ pode ser obtida facilmente no receptor, de modo que assume a informação de canal lateral no receptor (CSIR). A capacidade pode ser dada em termos de informação mútua entre o vetor de entrada do canal $x$ e do vetor de saída $y$ através da equação 4-12:

$$
C=\max _{p(x)} I(X ; Y)=\max _{p(x)}[H(Y)-H(Y \mid X)]
$$

A partir da definição de entropia $H(Y \mid X)=H(n)$, que é a entropia do ruído; desde que a o ruído $n$ tem fixado a entropia independente da entrada de canal, maximizar a informação mútua é equivalente a maximizar a entropia 
em y.

Dada uma matriz de covariância $R_{x}$ no vetor de entrada $x$, a matriz de covariância de saída $R_{y}$, associada com a saída de canal MIMO y, é dada por:

$$
R_{y}=E\left[y y^{H}\right]=\mathbf{H} R_{x} \mathbf{H}^{H}+\mathbf{I}_{N_{r}}
$$

Isto é, para todos os vectores aleatórios com matriz de covariância dada $\left(R_{y}\right)$,a entropia de $y$ é maximizada quando $y$ é um vetor aleatório Gaussiano complexo circularmente simétrico de média zero (ZMCSCG), mas $y$ é apenas ZMCSG se a entrada $x$ é tambem ZMCSG e, portanto, esta é a distribuição ótima em $x$ na equação 4-12, sujeita ao limite de potência $\operatorname{Tr}\left(R_{x}\right)=\rho$ (mostrado na equação $\left.2-2\right)$. Nesse caso $H(Y)=B \log _{2} \operatorname{det}\left[\pi e R_{y}\right]$ e $H(n)=B \log _{2} \operatorname{det}\left[\pi e \mathbf{I}_{N_{r}}\right]$, resultando a informação mutua:

$$
I(X ; Y)=B \log _{2} \operatorname{det}\left[\mathbf{I}_{N_{r}}+\mathbf{H} R_{x} \mathbf{H}^{H}\right]
$$

A capacidade MIMO é atingida através da maximização da informação mútua (Equação 4-11) sobre todas as matrizes de covariância de entrada $R_{x}$, satisfazendo o limite de potência [3]:

$$
C=\max _{R_{x}: \operatorname{Tr}\left(R_{x}\right)=\rho}=B \log _{2} \operatorname{det}\left[\mathbf{I}_{N_{r}}+\mathbf{H} R_{x} \mathbf{H}^{H}\right]
$$

A capacidade de um canal quase estático depende puramente da potência do sinal transmitido, do ruído e das características do canal. Para um canal determinístico de desvanecimento plano, a capacidade pode ser expressa como [10][4]:

$$
C=\log _{2}\left[\operatorname{det}\left[\mathbf{I}_{N_{r}}+\frac{\rho}{N_{t}} \mathbf{H} \mathbf{H}^{H}\right]\right]
$$

Onde $\rho=\frac{P}{\sigma_{n}^{2}}$, $\mathrm{P}$ é o sinal transmitido e $\sigma_{n}^{2}$ é a potência de ruído.

Em um caso limitado assumimos um canal com caminhos não correla- 
cionados e, consequentemente, o produto $\mathbf{H H}^{H}$ tem todos os autovalores $\lambda_{i}$ diferentes de zero e aproximadamente iguais. A capacidade é expressa como:

$$
C=\sum_{i=1}^{N} \log _{2}\left(1+\frac{\lambda_{i}}{N_{t}} \rho\right) \approx N \log _{2}\left(1+\frac{N_{r}}{N} \rho\right)
$$

Onde $N=\min \left(N_{r}, N_{t}\right)$

Telatar [4] ampliou a expressão para a capacidade ergódica em um canal aleatório Gaussiano de tempo variante. Descobriu que a capacidade ergódica cresce linearmente com o número de antenas de recepção para um grande número de antenas de transmissão.

\section{4}

\section{Conclusões}

Neste capítulo foi apresentada a teoria utilizada para projetar o sistema MIMO desejado, incluindo os modelos do transmissor, receptor, modulações, assim como as técincas de multiplexação espacial que garantem uma boa SNR em função do número de antenas. 


\section{Antenas}

Para uma frequência alta como $10 \mathrm{GHz}$, o tamanho da antena é limitado a apenas alguns centímetros, o que leva a optar pela utilização de antenas planares (patch antennas) na implementação do sistema MIMO em questão.

As antenas de microfita consistem em uma linha microstrip de alimentação de impedância de $50 \Omega$ em um substrato dielétrico de espessura (h) e metalização de cobre com espessura (t) onde $t \ll \lambda_{o}$ (comprimento de onda no espaço livre) e ( $h \ll \lambda_{o}$, em geral $\left.0.003 \lambda_{o} \leq h \leq 0.05 \lambda_{o}\right)$ considerando o plano de terra apresentado na figura 5.1.

Para um patch retangular, o comprimento L é geralmente dimensionado de acordo com a relação $\lambda_{o} / 3<L<\lambda_{o} / 2$. A fita (patch) e o plano de terra estão separados por uma folha dielétrica (substrato)[18].

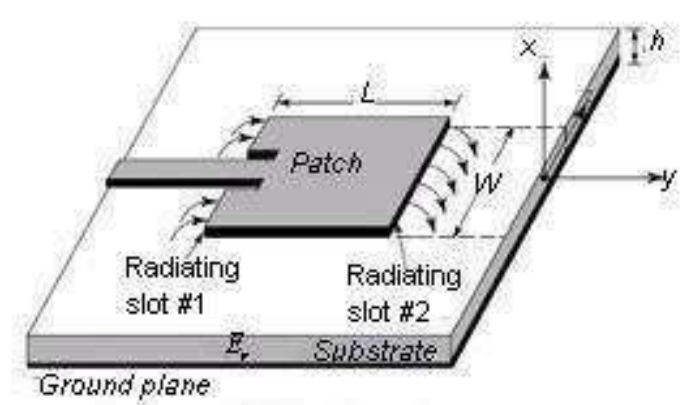

(a) Antena de microfita

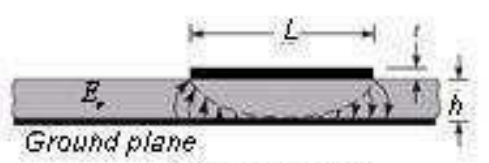

(b) Vista lateral

Figura 5.1: Antena de microfita

A ferramenta computacional da Ansoft HFSS conhecida como Antenna Designer Kit auxilia no dimensionamento adequado deste tipo de antena. 
As antenas de microfita são dispositivos com elevado fator de seletividade de resonância Q, às vezes superando o valor de 100 para elementos mais finos. Elementos com alto Q têm largura de banda pequena.

As razões pelas quais as antenas de microfita tornaram-se populares incluem:

- São antenas de baixo perfil.

- São facilmente adaptáveis a superfícies não planares.

- São baratas e fáceis de fabricar em grandes quantidades usando técnicas modernas de circuito impresso.

- Quando montadas sobre uma superfície rígida são mecanicamente robustas.

- São elementos versáteis no sentido de que elas podem ser projetadas para produzir una ampla variedade de padrões de polarização, dependendo do modo de excitação e da forma particular de patch usada.

- Elementos adaptivos podem ser feitos simplesmente adicionando diodos pin ou varactor devidamente situados entre o patch e o plano de terra. Usando tais elementos de carga, pode-se variar a frequência de ressonância da antena. [19]

\section{1}

\section{Antena Patch Retangular}

O patch retangular é, a configuração mais amplamente usada. É fácil de analisar utilizando o modelo de linha de transmissão e de cavidade, que é mais preciso para substratos finos.

\subsection{1}

\section{Modelo de linha de transmissão}

Este modelo é mais simples de todos, mas dá resultados menos precisos e não tem versatilidade. Não obstante, produz um pouco de visão física. Basicamente, o modelo de linha de transmissão representa à antena de microfita em dois slots(fendas), separadas por uma linha de transmissão de baixa impedância Zc e de comprimento L. 


\section{1 .2}

\section{Efeito de franjamento ou bordas (Fringing)}

Dado que as dimensões do patch são finitas ao longo do comprimento e largura, os campos nas bordas do patch sofrem de efeito de franjamento. O efeito é mostrado na figura 5.2. A quantidade de dispersão é uma função das dimensões do patch e da altura do substrato e faz com que a linha de microfita pareça eletricamente mais larga em comparação com as suas dimensões físicas. Uma vez que as ondas viajam no substrato e outras no ar, considera-se uma constante dielétrica efetiva $E_{\text {reff }}$ do material dielétrico ar+substrato ilustrado na figura 5.2.

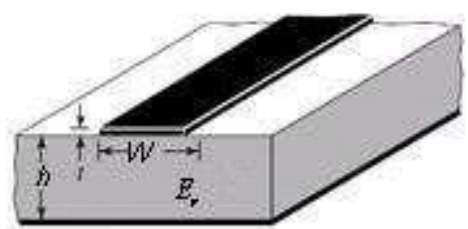

a) Microfita

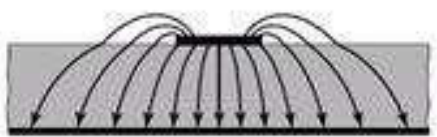

b) Linhas de Campo Elétrico

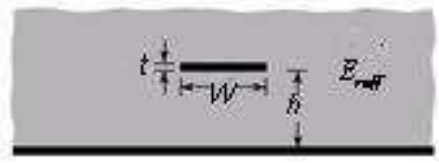

c) Constante dielétrico

Figura 5.2: Linhas de campo e constante dielétrica efetiva em uma linha de microfita

Para uma linha microstrip sobre o substrato, a constante dielétrica efetiva é definida entre o intervalo de $1<E_{\text {reff }}<E_{r}$. Esta constante é também uma função da frequência. À medida que aumenta, a maioria das linhas de campo elétricas ficam concentradas no substrato e, portanto, a linha de microfita se comporta como uma linha mais homogênea de um dielétrico (apenas substrato), e $E_{\text {reff }}$ atinge o valor da constante dielétrica do substrato. [18]

Esta constante é dada em termos da constante elétrica relativa do substrato $E_{r}$, de acordo com:

$$
E_{\text {reff }}=\frac{E_{r}+1}{2}+\frac{E_{r}-1}{2}\left[1+\frac{12 h}{W}\right]^{-1 / 2}
$$


onde $W$ é a largura do patch.

Devido aos efeitos de franjamento, o patch da antena de comprimento $L$ pode variar de $\Delta L$, que é uma função do $E_{\text {eff }}$ e da razão $W / h$. Uma boa estimativa desta distância, que tem sido frequentemente usado com sucesso, é a equação apresentada em 5-2 [18][19]:

$$
\Delta L=0.412 h \frac{\left(E_{\text {reff }}+0.3\right)\left(\frac{W}{h}+0.264\right)}{\left(E_{\text {reff }}-0.258\right)\left(\frac{W}{h}+0.8\right)}
$$

Agora, o comprimento efetivo do patch é:

$$
L_{e f f}=L+2 \Delta L
$$

Tendo um diagrama como a da figura 5.3, pode-se calcular a distância necessária para ter as duas antenas descorrelatadas.

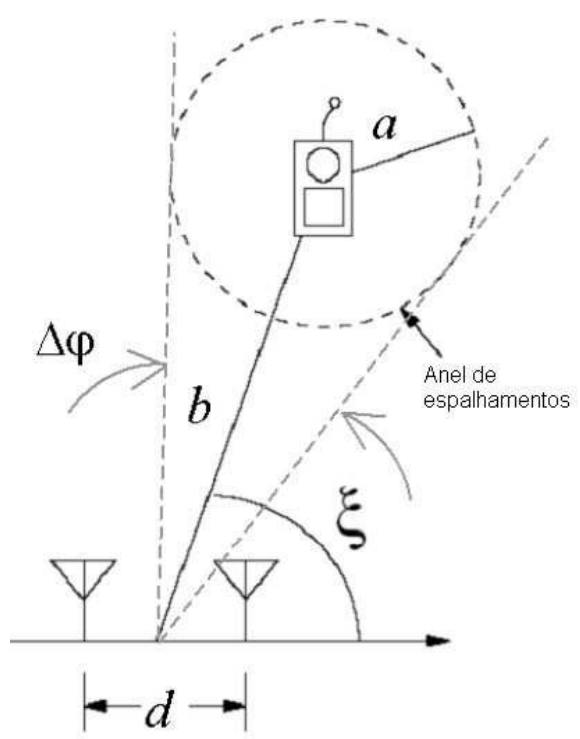

Figura 5.3: Cenário de diversidade espacial

$\Delta \varphi=2 a / b$ onde $\Delta \varphi$ é a largura de feixe do diagrama de radiação no ponto de $3 \mathrm{~dB}$. Deve-se ressaltar que $\Delta \varphi$ não se refere à abertura de feixe do 
diagrama de radiação real das antenas da estação-base mas, sim, à abertura do feixe capaz de concentrar energia no círculo de ráio a [8].

Se, baseado no setup para medir o diagrama de radiação das antenas e a sua descorrelação, o valor de $a=1.5 \mathrm{~m}$ e $b=1.5 \mathrm{~m}$, o coeficiente de correlação espacial entre duas envoltórias com distribuição Rayleigh, cada uma associada a uma das antenas de transmissão, é calculado por [8]:

$$
\rho=J_{o}\left[\frac{a}{b} 2 \pi \frac{d}{\lambda} \operatorname{sen}(\xi)\right] J_{o}^{2}\left[\frac{1}{2}\left(\frac{a}{b}\right)^{2} 2 \pi \frac{d}{\lambda} \sqrt{1-\frac{3}{4} \cos ^{2}(\xi)}\right]
$$

onde $J_{o}(u)$ é a Função de Bessel de primeira espécie e ordem zero, $\lambda$ é o comprimento da onda eletromagnética, $a, b, d$ e $\xi$ estão definidos na figura 5.3

A partir da equação 5-4, o gráfico de correlação espacial fica como o da figura 5.4, no qual foi se variando a distância entre as duas antenas para um comprimento de onda eletromagnética fixo, que corresponde à frequência de $10 \mathrm{GHz}$ (frequência de operação das antenas projetadas). O gráfico mostra que a partir de $0.5 \lambda$, aproximadamente, os valores de correlação vão ser menores que 0.1, portanto, essa será a distância mínima para a separação das antenas MIMO.

\section{2 \\ Conclusões}

Apresentou-se as antenas planares do sistema MIMO. As antenas de microfita tem vantagens em custo e fabricação, além de que são ótimas para frequências altas. O projeto de uma antena patch depende dos efeitos de franjamento para obter a frequência de corte desejada. 


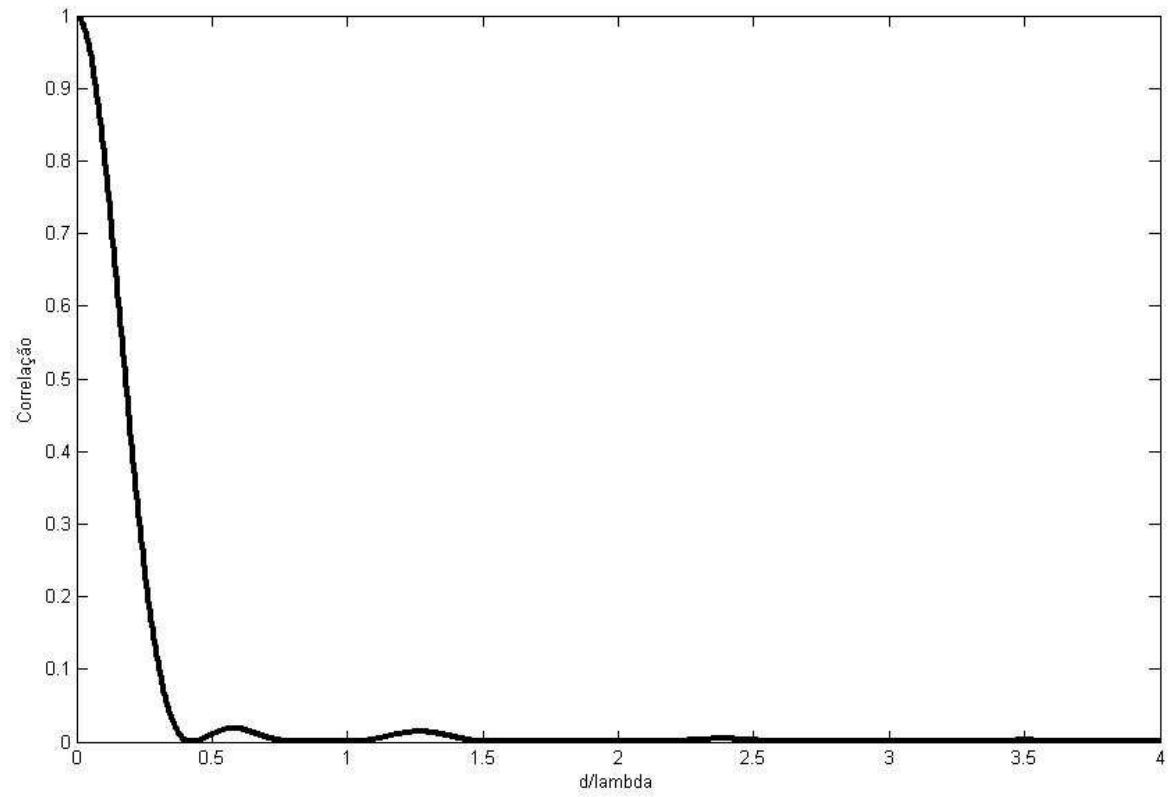

Figura 5.4: Coeficiente de correlação espacial em função de $d / \lambda$ e de $a / b$. $\xi=90^{\circ}$ 


\section{6 \\ Desenvolvimento do sistema MIMO 2×2}

Este capítulo apresenta o desenvolvimento do sistema MIMO 2x2, baseado na teoria do capítulo 4, visando uma futura implementação com tecnologia FPGA. Para isto, técnicas de simulação na ferramenta computacional SystemVue (Agilent) são realizadas e os resultados são apresentados. Ainda neste capítulo, as antenas patch são dimensionadas, simuladas e caracterizadas, experimentalmente, de forma a aplicá-las em um sistema MIMO em $10 \mathrm{GHz}$.

A figura 6.1 ilustra o sistema completo simulado. Em cada uma das seções do presente capítulo serão explicadas os blocos principales do setup.

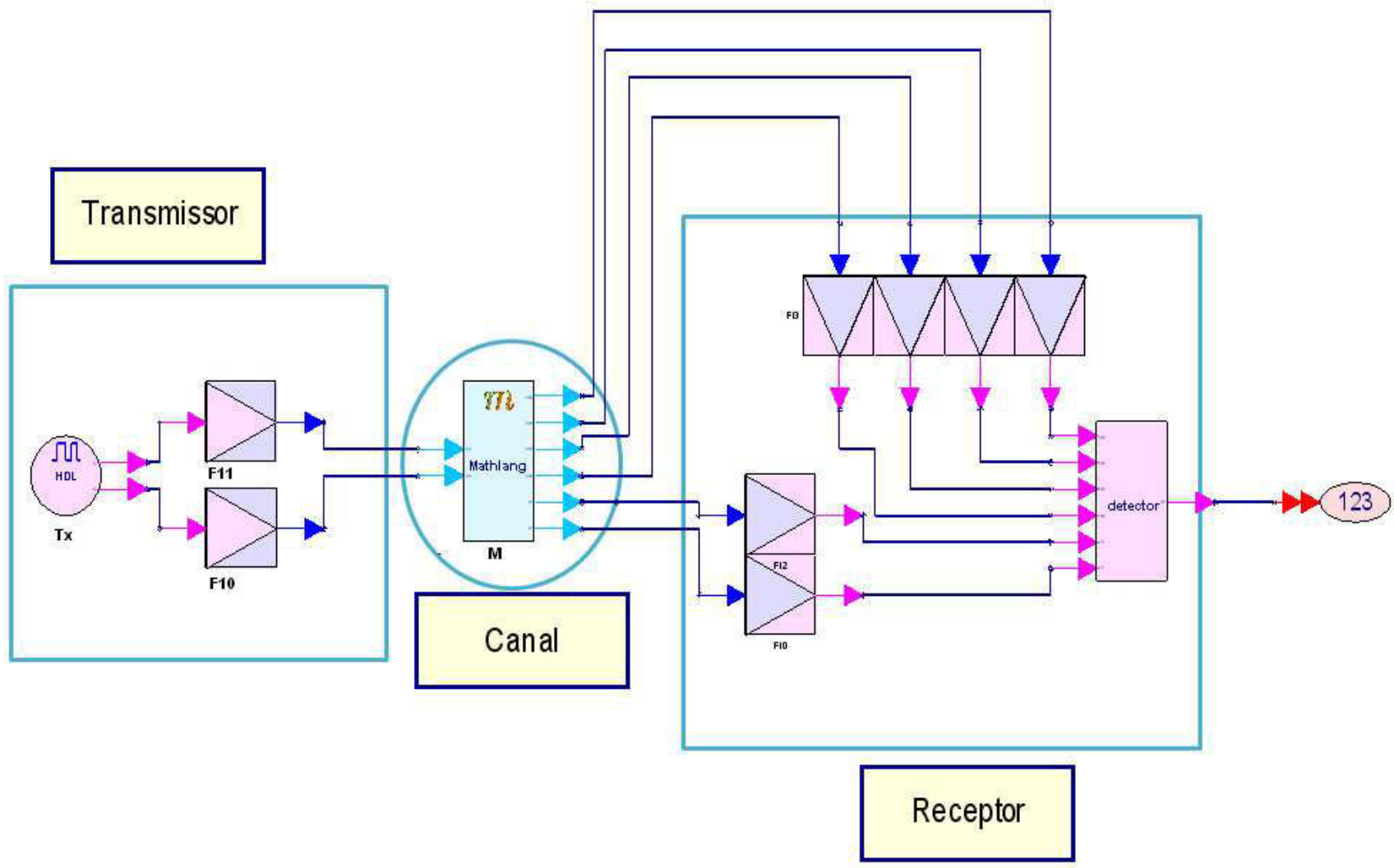

Figura 6.1: Sistema MIMO 2x2 


\section{1 \\ Ferramentas utilizadas}

\subsection{1}

\section{Xilinx ISE Design Suite}

É uma ferramenta de software produzida por Xilinx para a compilação, síntese e implementação de projetos digitais logicamente programáveis (FPGA) que utilizam a linguagem VHDL (VHSIC (Very High Speed Integrated Circuits) Hardware Description Language) para a sua realização, que permite ao desenvolvedor sintetizar os projetos de eletronica digital, executar análise de tempo, examinar diagramas RTL (visualização do código em sua equivalente de portas lógicas ou em flip flops) e configurar a placa do dispositivo. Este software foi utilizado para programar o algoritmo de cada um dos blocos do sistema transmissor e receptor.

\section{1 .2 \\ SystemVue}

É um ambiente de automatização de desenho eletrónico (EDA) focado para projetos de nível de sistema eletrônico (ESL). Permite arquiteturas de sistema e desenvolvimento de algoritmos para inovar a camada física (PHY) de sistemas de comunicações aeroespaciais/defesa sem fio e agrega um valor importante para projetos de RF por meio de DSP (Digital Signal Processor) e FPGA/ASIC (Field-Programmable Gate Array/Application-Specific Integrated Circuit). Como uma plataforma dedicada para realização de processamento de sinal e desenho para ESL, SystemVue substitui ambientes de propósito geral (digital, analógico e matemático). A vantagem é que permite utilizar blocos de diferentes linguagens de programação no mesmo ambiente, portanto, este software foi útil na hora de simular o sistema utilizando diferentes blocos como HDL, matlab e os próprios do SystemVue.

\subsection{3}

\section{Matlab}

É um ambiente de programação para o desenvolvimento de algoritmos, análise de datos, visualização e computação numérica. O software foi utilizado para simular o ambiente do canal e para fazer comparações nos testes do sistema. 


\subsection{4}

\section{Advanced Design System (ADS)}

É um software de automação muito usado e que trabalha com desenho eletrônico para RF, microondas e aplicações digitais de alta velocidade, em uma interface poderosa e fácil de usar. ADS é pioneiro das tecnologias mais inovadoras e bem sucedidas comercialmente, tais como os parâmetros $\mathrm{X}$ e simuladores eletromagnetico 3D. Utilizado por empresas líderes em comunicação e redes sem fio e também, em indústrias aeroespacias e defesa. Esse software ajudou no desenho e simulação das antenas de microfita para uma frequência de $10 \mathrm{GHz}$, assim como o desenho do divisor de potência para os testes do array de multiplas antenas.

\section{2}

\section{Simulação do Transmissor}

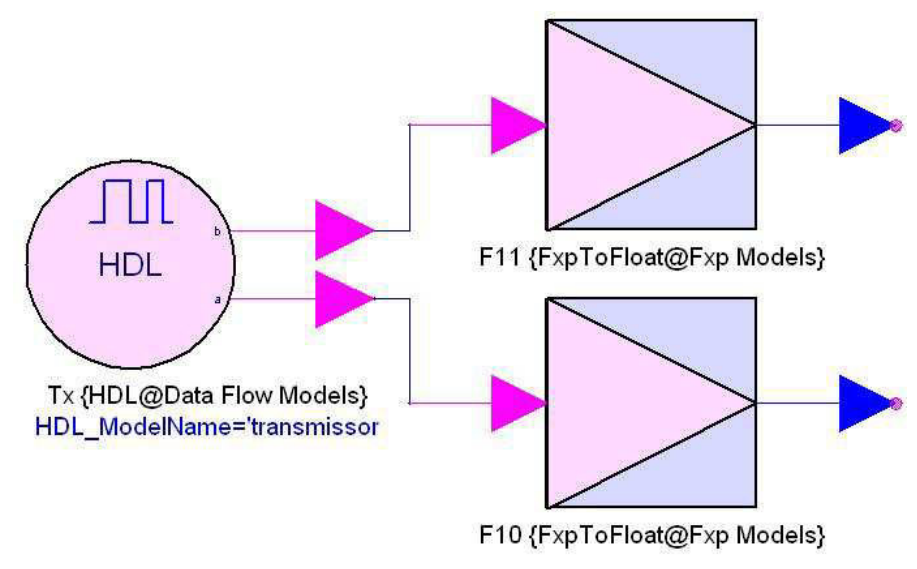

Figura 6.2: Bloco do Transmissor feito em VHDL

O Transmissor está composto de um bloco em HDL, que na figura 6.2 tem o nome de "Tx". Esse bloco contém o algoritmo feito com ajuda do software Xilinx ISE, no qual foram desenvolvidos o gerador de sinais PRBS (Pseudo Random Binary Sequence), o modulador BPSK e o multiplexador 1x2 (mostrados na seção 4.1a) de forma a gerar dois sinais de saídas "a"e " $b$ " digitais, que são salvos em um arquivo do formato .vhd para poder ser incluido no bloco HDL. As portas do bloco Tx são as saídas com o sinal demultiplexado e modulado em BPSK, que vaõ passar por um bloco de conversão de número em ponto fixo (tipo de dado em VHDL para números decimais) a float (números reais). A figura mostra o bloco para inserir o código 
gerado em VHDL do transmissor MIMO.

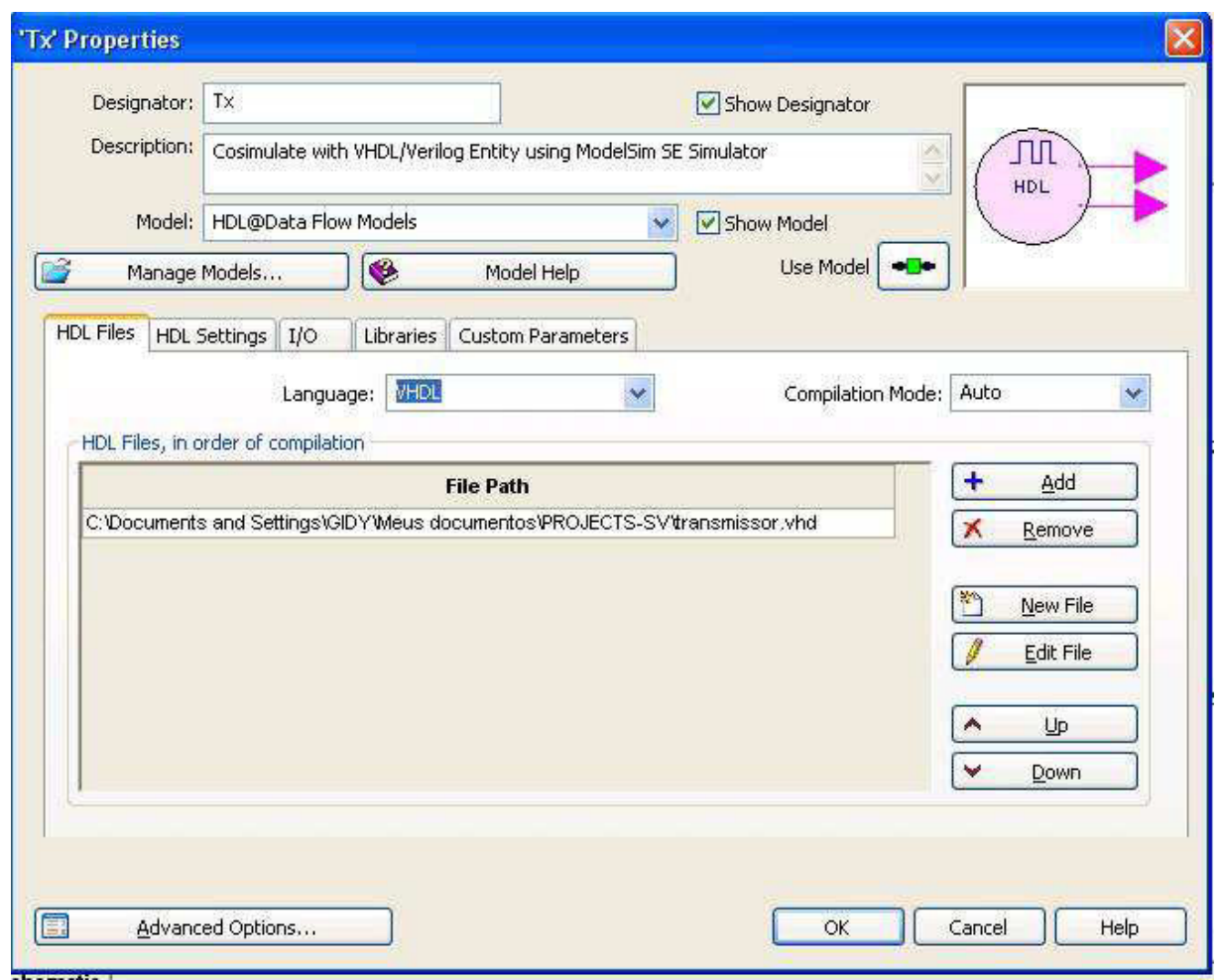

Figura 6.3: Visão do bloco HDL

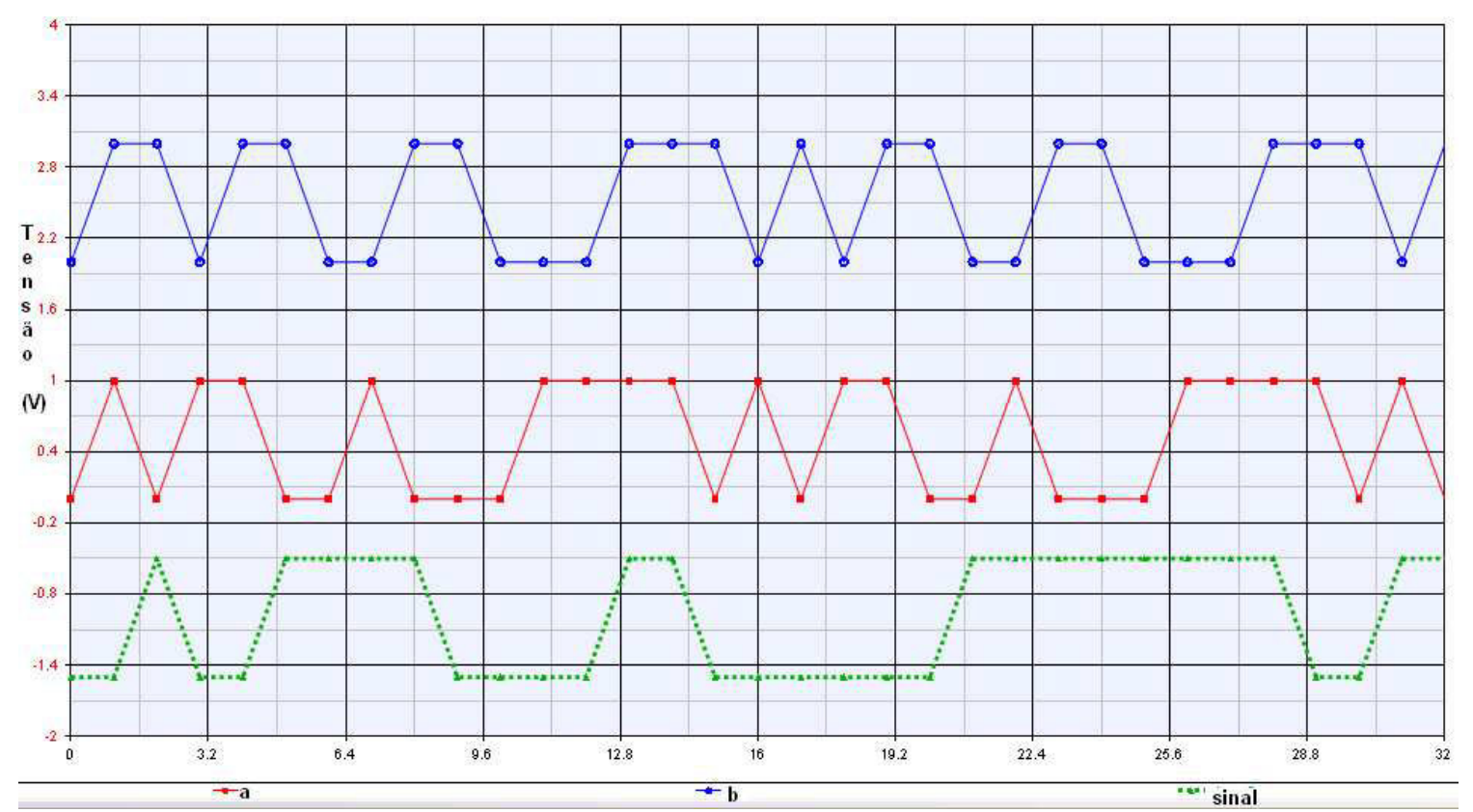

Figura 6.4: Gráfico do sinal gerado e sua multiplexação

Pode-se observar, na figura 6.4, a multiplexação do sinal gerado. 
As saidas do Transmissor serão portanto:

$$
s= \begin{cases}+1 & \text { se bit }=1 \\ -1 & \text { se bit }=0\end{cases}
$$

Na figura 6.5 está o mapeamento do sinal multiplexado.

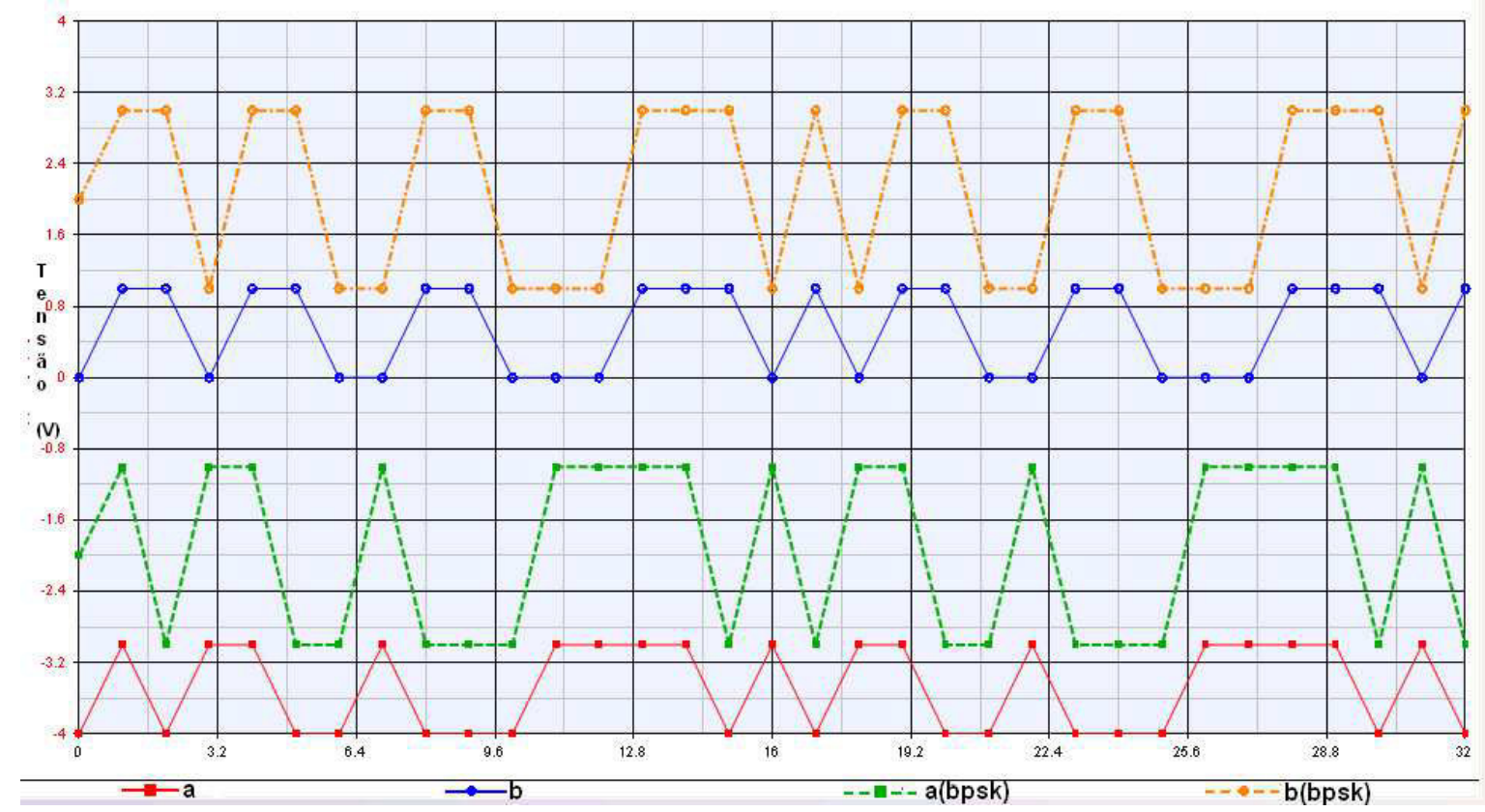

Figura 6.5: Mapeamento em BPSK dos sinais multiplexados

\section{3 \\ Simulação do Canal}

Na figura 6.6, apresenta-se o bloco de simulação do canal, que neste caso é um canal Rayleigh de desvanecimento plano. Internamente estão descritos o tipo de canal e o ruído de cada receptor, modelado como Gaussiano branco de variancia 1. As portas "in1"e "in2"saõ as entradas do sinal gerado pelo Transmissor da figura 6.2 os quais são do tipo float.

O bloco tem as portas de saída "y1"e "y2", que simulam os símbolos enviados pelo transmissor, alterados pelos efeitos do ambiente Rayleigh (como foi descrito no capítulo 3) e o ruído de cada receptor. Cada uma das portas do canal são os elementos da matriz $\mathbf{H}$, que no caso de um sistema MIMO é:

Número de Transmissores x Número de Receptores, 
portanto, são 4 elementos da matriz $\left(h_{1} 1, h_{1} 2, h_{2} 1, h_{2} 2\right)$, colocados na saída do bloco feito em Matlab.

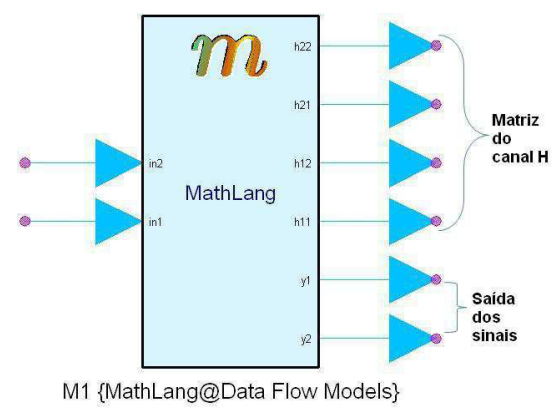

Figura 6.6: Bloco de simulação do canal Rayleigh feito mediante código em Matlab

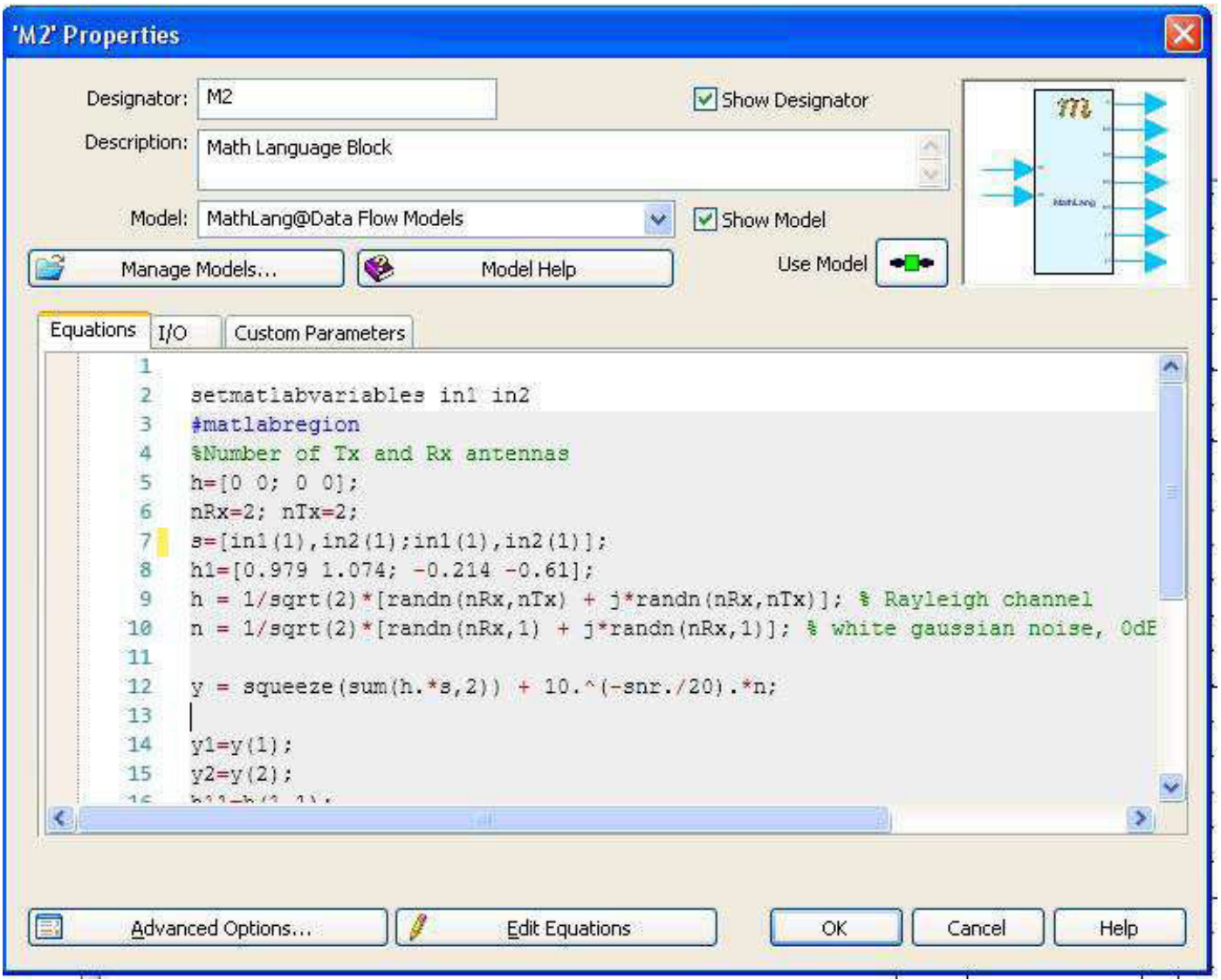

Figura 6.7: Visão interna do bloco do simulador de canal

O código foi baseado de acordo com o modelo do canal Rayleigh [9], modificando alguns parámetros para que o software System Vue pudesse simulá-lo de acordo com o compilador do software. A figura 6.7 mostra parte do código 
que simula o canal.

A figura 6.8 ilustra como os sinais das saídas do transmissor são afetados pelo canal Rayleigh.

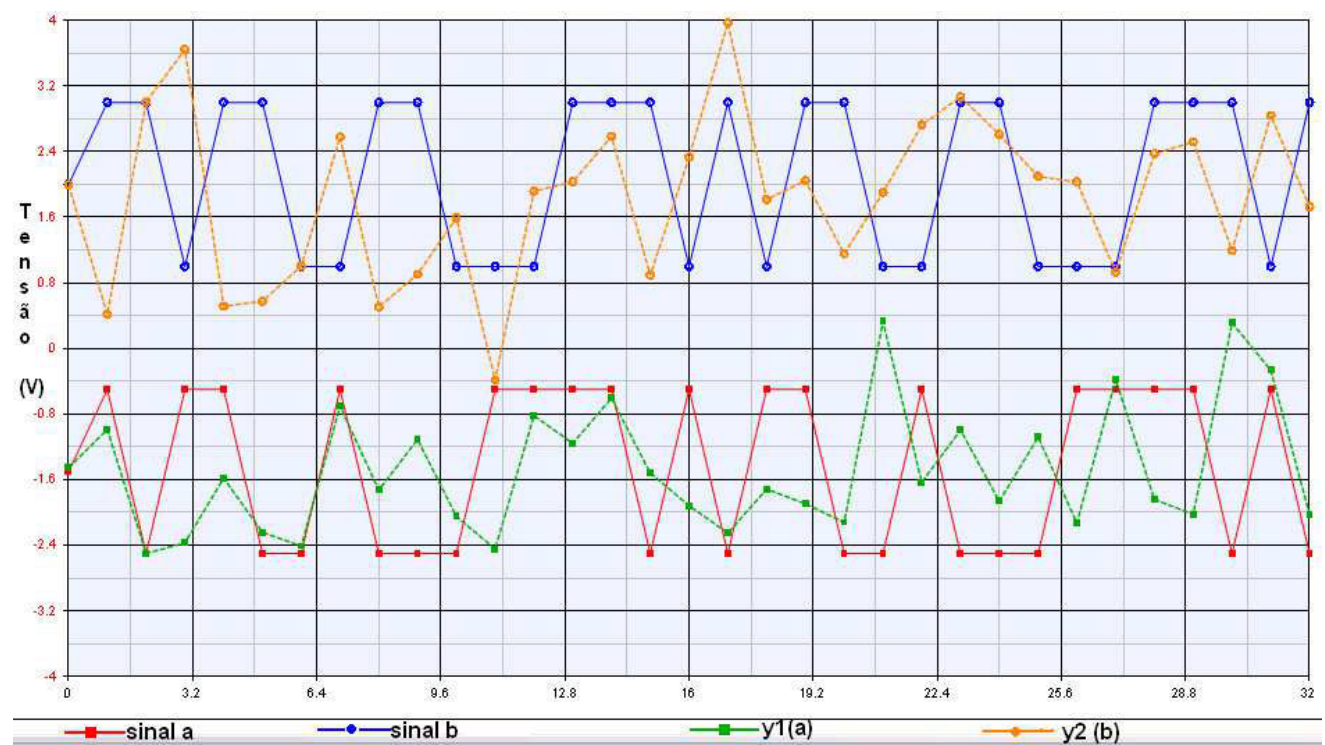

Figura 6.8: Sinais da saida da transmissão alterados pelos efeitos do canal Rayleigh

\section{4 \\ Simulação do Receptor}

O Receptor consiste na implementação em VHDL, do decisor e do estimador de canal de forma a recuperar o sinal transmitido conforme apresentado no capítulo 4. O equalizador é feito de blocos em ponto fixo, os quais são blocos feitos para poder realizar a geração do código em VHDL. Eles devem ser modificados de acordo com o comprimento de cada palavra e a resolução de bit desejado, pois o receptor utiliza números decimais positivos e negativos.

Como pode ser visto na figura 6.9 , há 6 blocos que vão converter os valores da saída do canal e dos sinais alterados por este (que são do tipo real) a valores em ponto fixo, o que significa que vai converter a bits. Um exemplo é mostrado na figura 6.10 


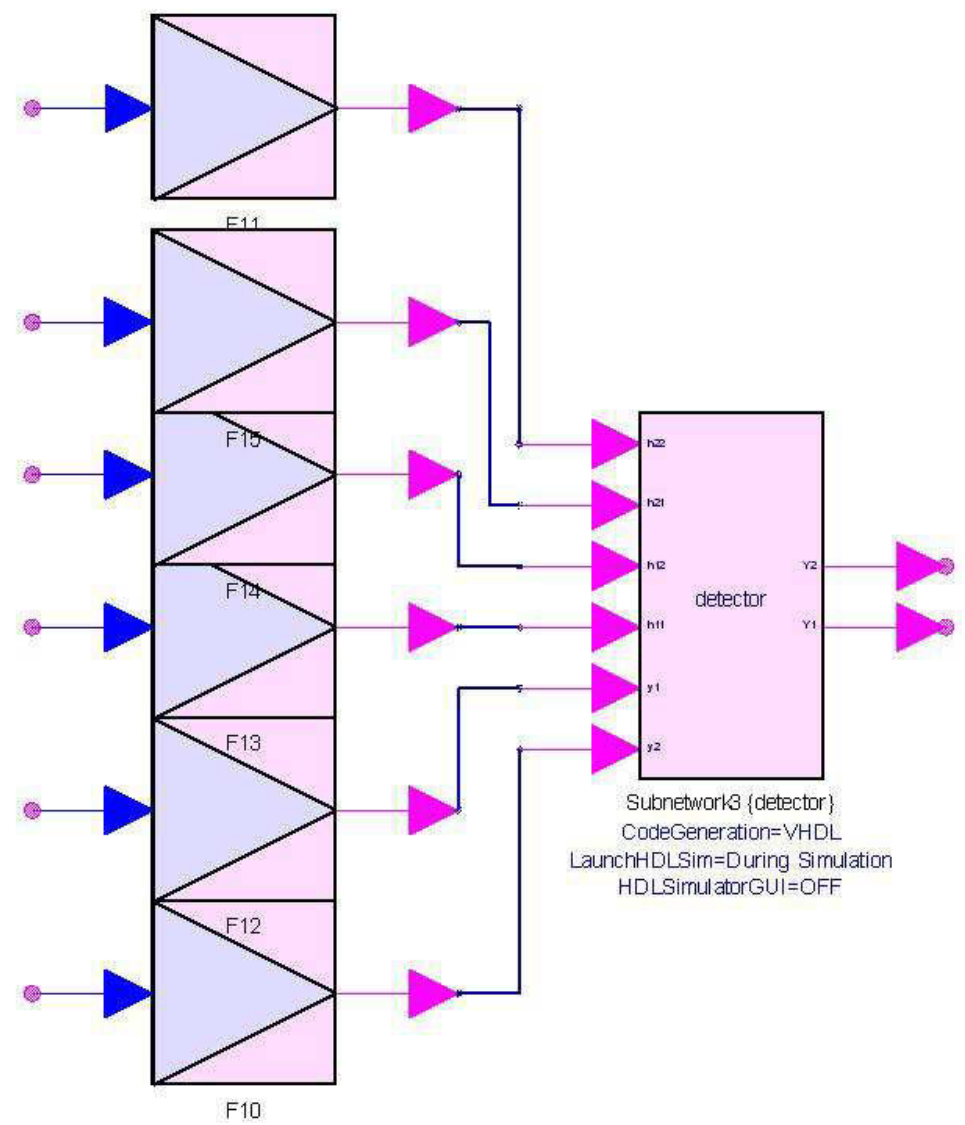

Figura 6.9: Bloco do Receptor

Para o equalizador MMSE, o código foi baseado no modelo apresentado em [9], cuja equação 4-9 foi apresentada, anteriormente, no capítulo 4, para obter a equação 4-10. Assim, cada um das operações, seja de multiplicação, soma ou inversão de matrices, foram convertidas a blocos de somas, subtrações, divisões e multiplicações de elementos, para utilizar as ferramentas fornecidas pelo SystemVue e minimizar o tempo de programação do receptor. Deste modo, foi obtido o diagrama da figura 6.11.

Como exemplo, na inversão de uma matriz 2x2, tem-se:

$\mathbf{H}^{-1}=\left[\begin{array}{ll}h_{11} & h_{12} \\ h_{21} & h_{22}\end{array}\right]^{-1}=\frac{1}{\operatorname{det}(\mathbf{H})}\left[\begin{array}{cc}h_{22} & -h_{12} \\ -h_{21} & h_{11}\end{array}\right]=\frac{1}{h_{11} h_{22}-h_{12} h_{21}}\left[\begin{array}{cc}h_{22} & -h_{12} \\ -h_{21} & h_{11}\end{array}\right](6-2)$ 


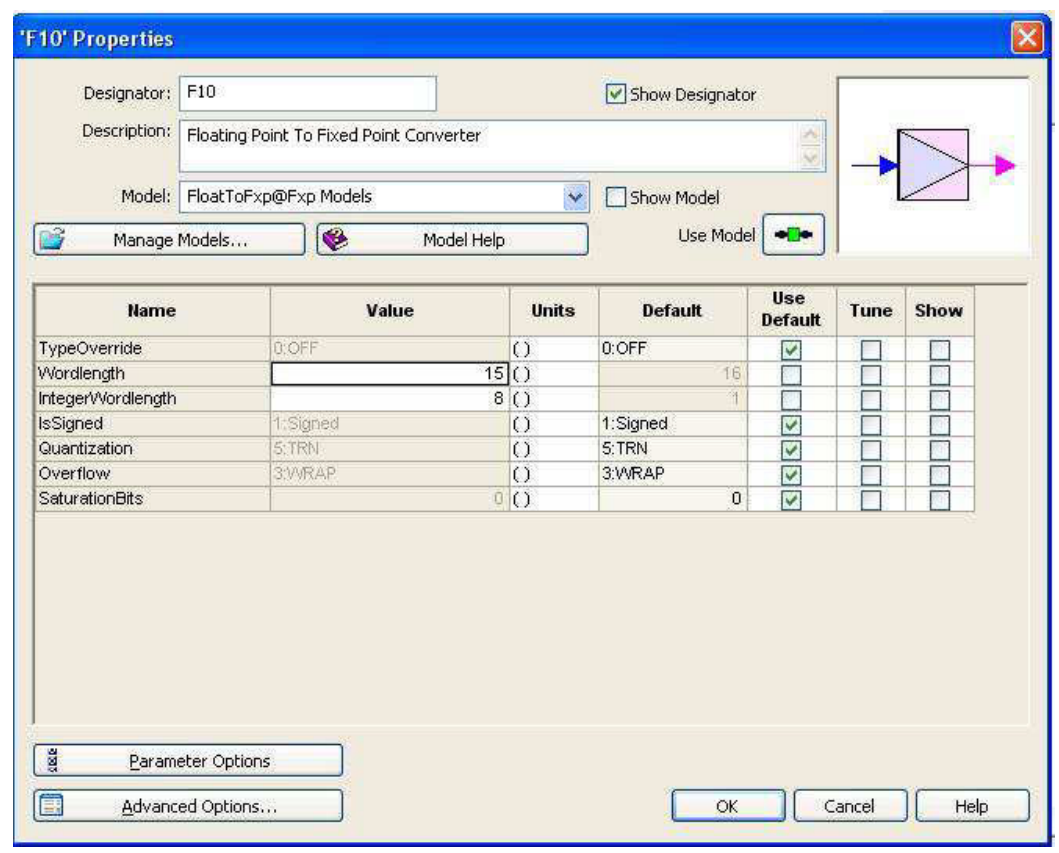

Figura 6.10: Conteúdo do bloco de conversão de fixo a real

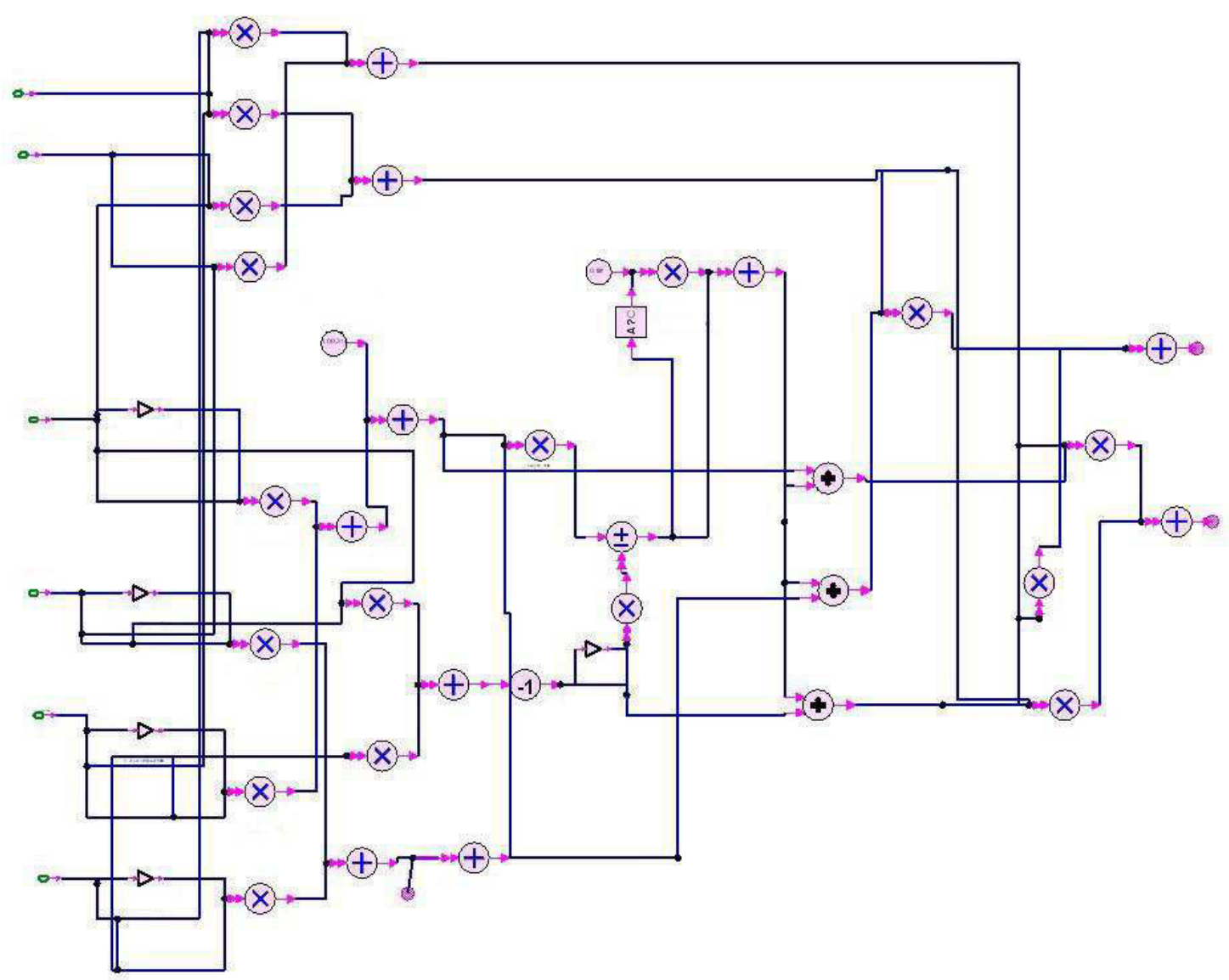

Figura 6.11: Seção do equalizador dentro do bloco do receptor 
O detetor de limiar é colocado na saída da equalização dos sinais para fazer a comparação de níveis e, dependendo de como foi o mapeamento no transmisor 6.5, a operação contraria é feita no receptor onde o limiar é o nível 0. A figura 6.12 mostra os esquemas do detetor e multiplexador. A figura 6.13 mostra o sinal equalizado com a técnica MMSE e, na figura 6.14 o sinal reconstruido.
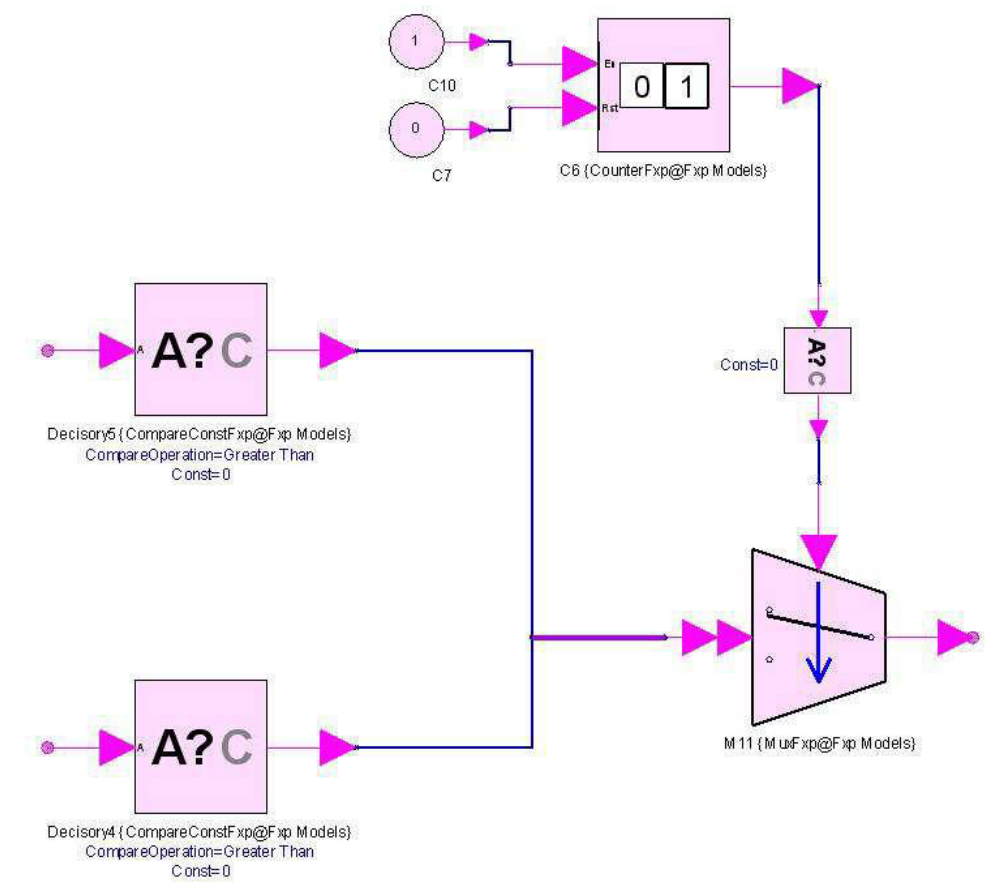

Figura 6.12: Detetor de limiar e multiplexador

\section{Taxa de Erro de Bit}

Para verificar se o sistema funciona corretamente, foi feita a medida de taxa de erro de bit (BER) com a ajuda do SystemVue por meio de um bloco que faz o cálculo dependendo da relação sinal-ruído (SNR)do sistema, a simulação foi realizada para valores de SNR de 0 - 30 dB(valor máximo permitido pelo software).

A figura 6.15 mostra que a melhor taxa de erro de bit é de $10^{-2}$, concordando com [21]. 


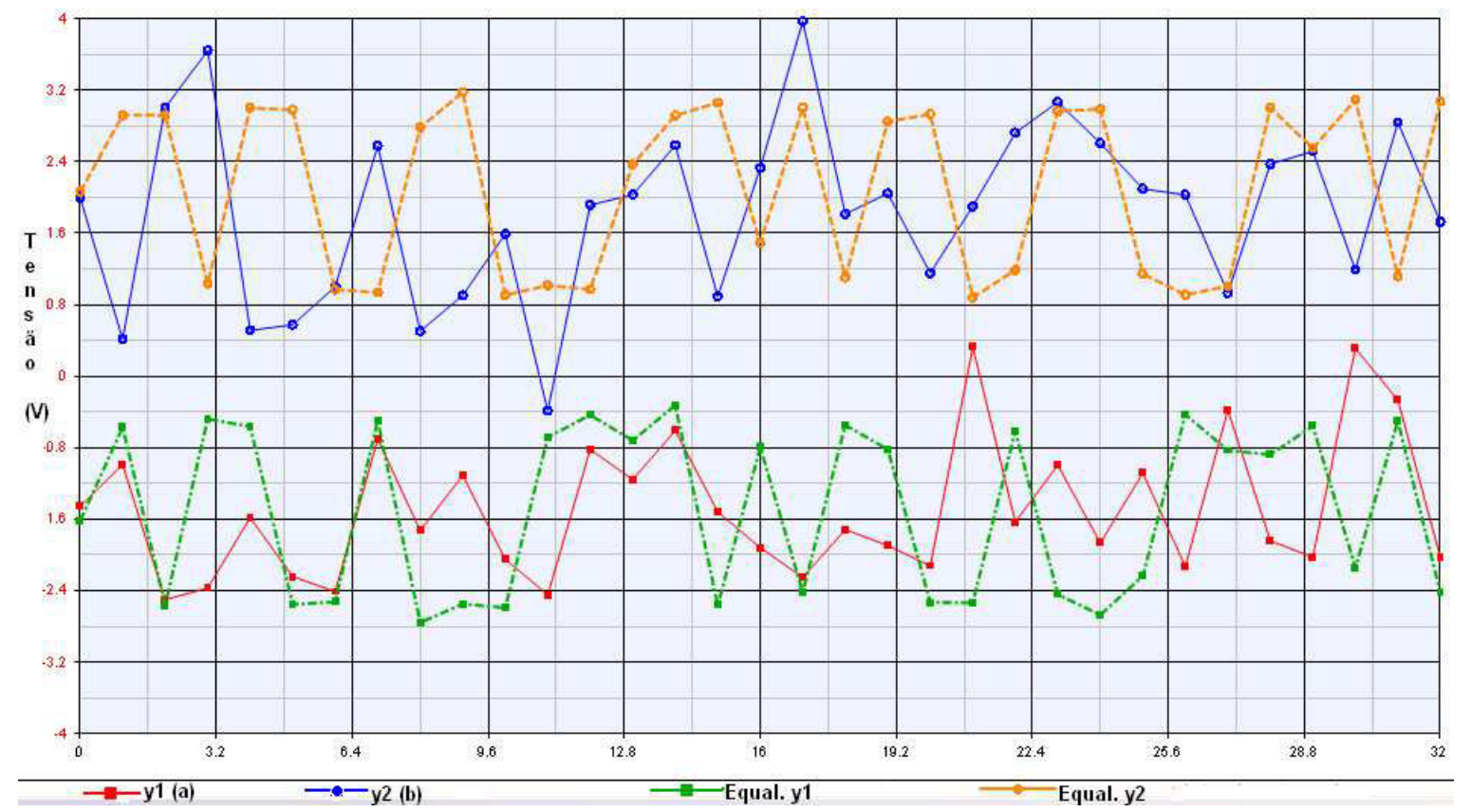

Figura 6.13: Sinal equalizado com o MMSE

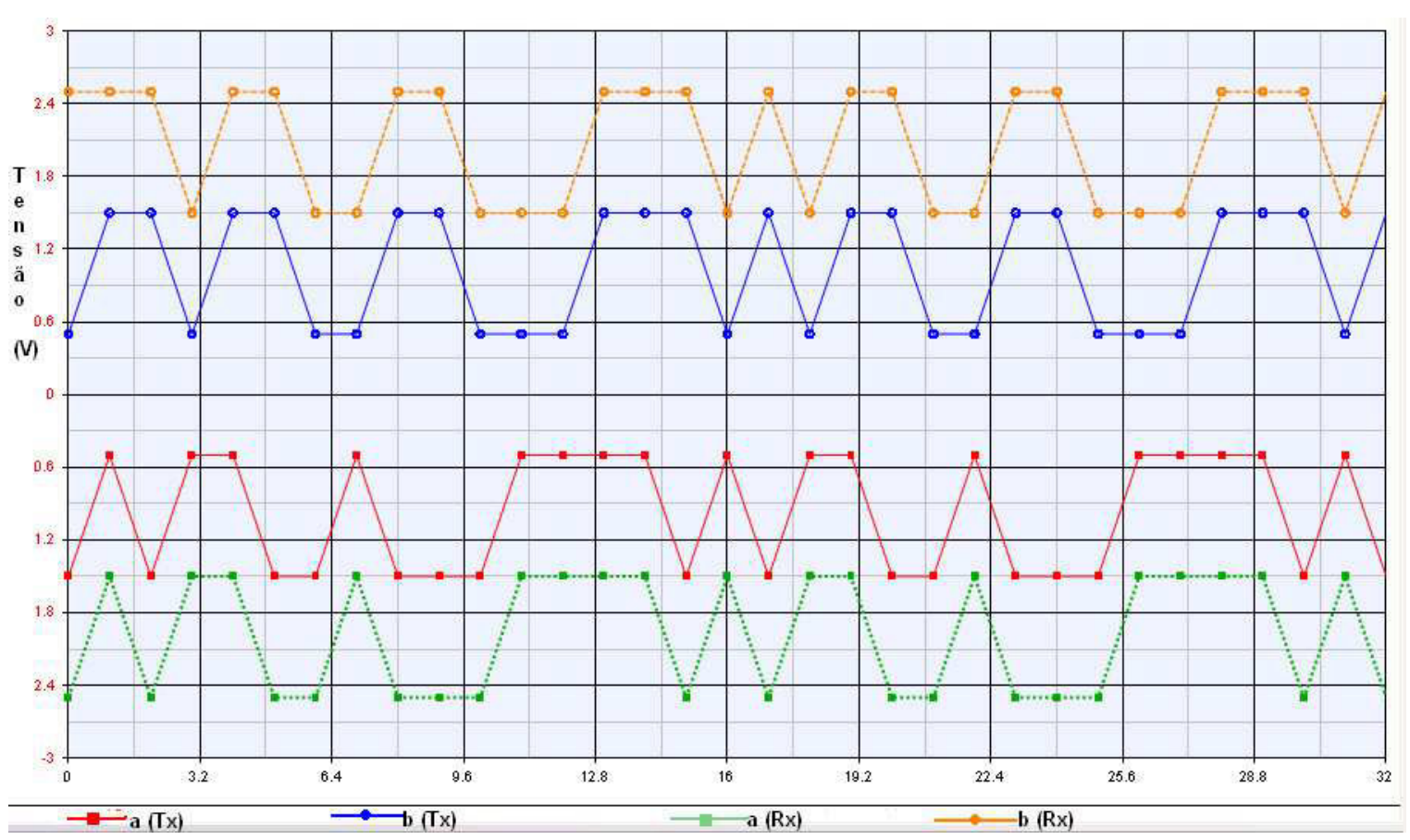

Figura 6.14: Sinal reconstruído, comparado com o sinal do transmissor

\section{Capacidade}

Para testar a vantagem na capacidade do sistema, ele foi comparado com um sistema 1x1 (SISO), 1x2 (SIMO) e 2x1 (MISO). Os resultados são apresentados na figura 6.16. Pode-se observar a diferença maior no arranjo de um sistema com duas antenas transmissoras e duas receptoras, onde o cres- 


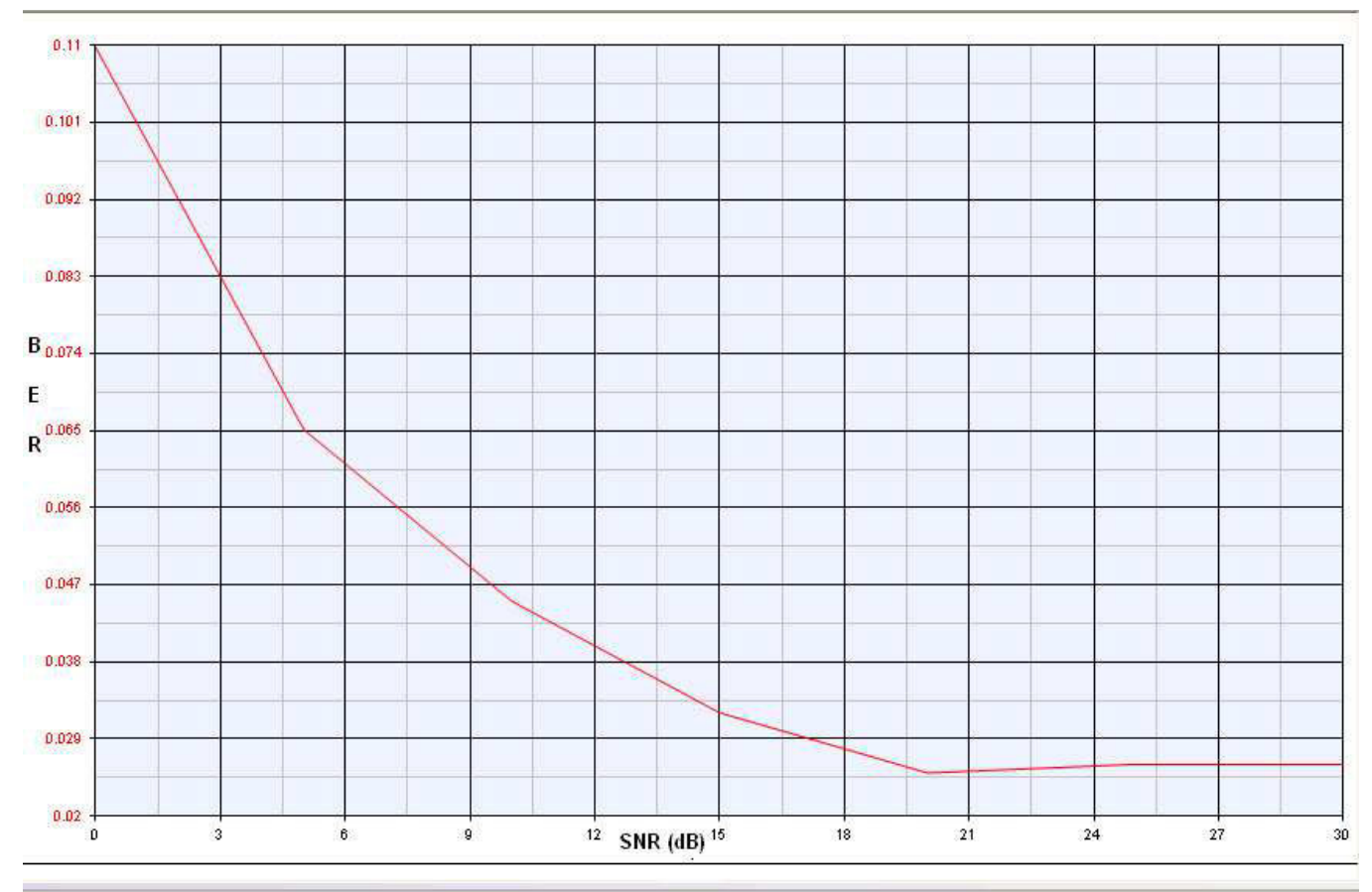

Figura 6.15: Taxa de erro de bit versus relação sinal-ruído do sistema

cimento da capacidade tem um comportamento logarítmico. Com o gráfico apresentado é visto que, em termos de relação sinal-ruído, as exigências são menores, e assim o uso de potências menores é possível.

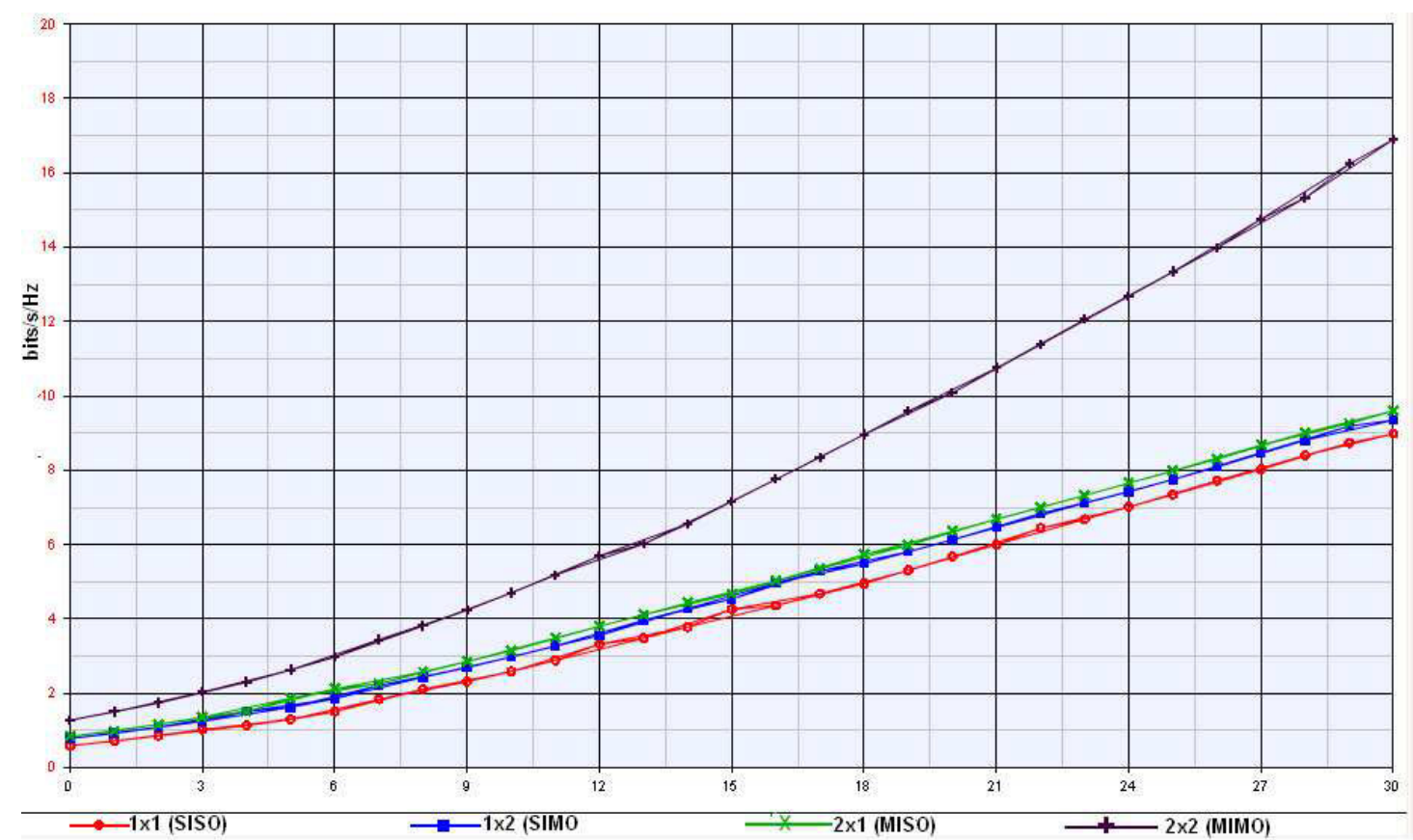

Figura 6.16: Comparação da capacidade x SNR em um sistema SISO(1x1), $\operatorname{MISO}(2 \times 1), \operatorname{SIMO}(1 \times 2)$ e MIMO 2x2 


\section{5}

\section{Fabricação das Antenas}

Como a frequência desejada para a operação das antenas é de $10 \mathrm{GHz}$, foram fabricadas antenas de microfita. Para um melhor desenvolvimento com um substrato Roger (RT5880) em $10 \mathrm{GHz}$, as antenas foram realizadas através do software Ansoft HFSS Antenna Design kit. A simulação realizada com o software Advanced Design System (ADS), de forma a avaliar o coeficiente de reflexão e o diagrama de irradiação da antena, para uma alimentação de $50 \Omega$, mostrou que o acoplamento de impedâncias não era o melhor, de modo que foi feito uma mudança na linha que iria ao conector da antena, melhorando o acoplamento. Os resultados do desenho são apresentados na figura 6.17.

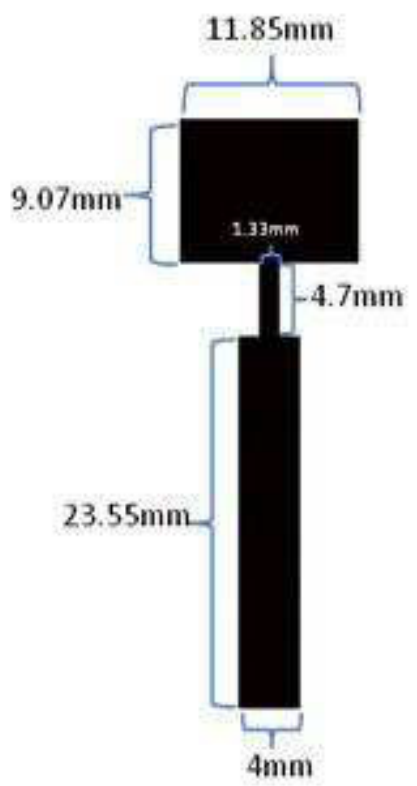

Figura 6.17: Medidas da antena para uma frequência de $10 \mathrm{GHz}$ feita no software ADS

Para as quatro antenas da figura 6.17, simuladas no ADS, mediu-se com o Analisador Vetorial de Rede o coeficiente de reflexão s11(dB) e os resultados são apresentados na figura 6.18. Tais resultados diferem entre si devido ao processo de elaboração das 4 antenas.

Realizou-se, também, o desenho de um array de 4 antenas alimentadas pela mesma entrada de potência, com distâncias entre elas de $\lambda / 2$ onde $\lambda$ é a razão entre a velocidade da luz $\left(3 \times 10^{8} \mathrm{~m} / \mathrm{s}\right)$ e a frequência de operação da antena; tal espaçamento evita as correlações entre os canais e o acoplamento 


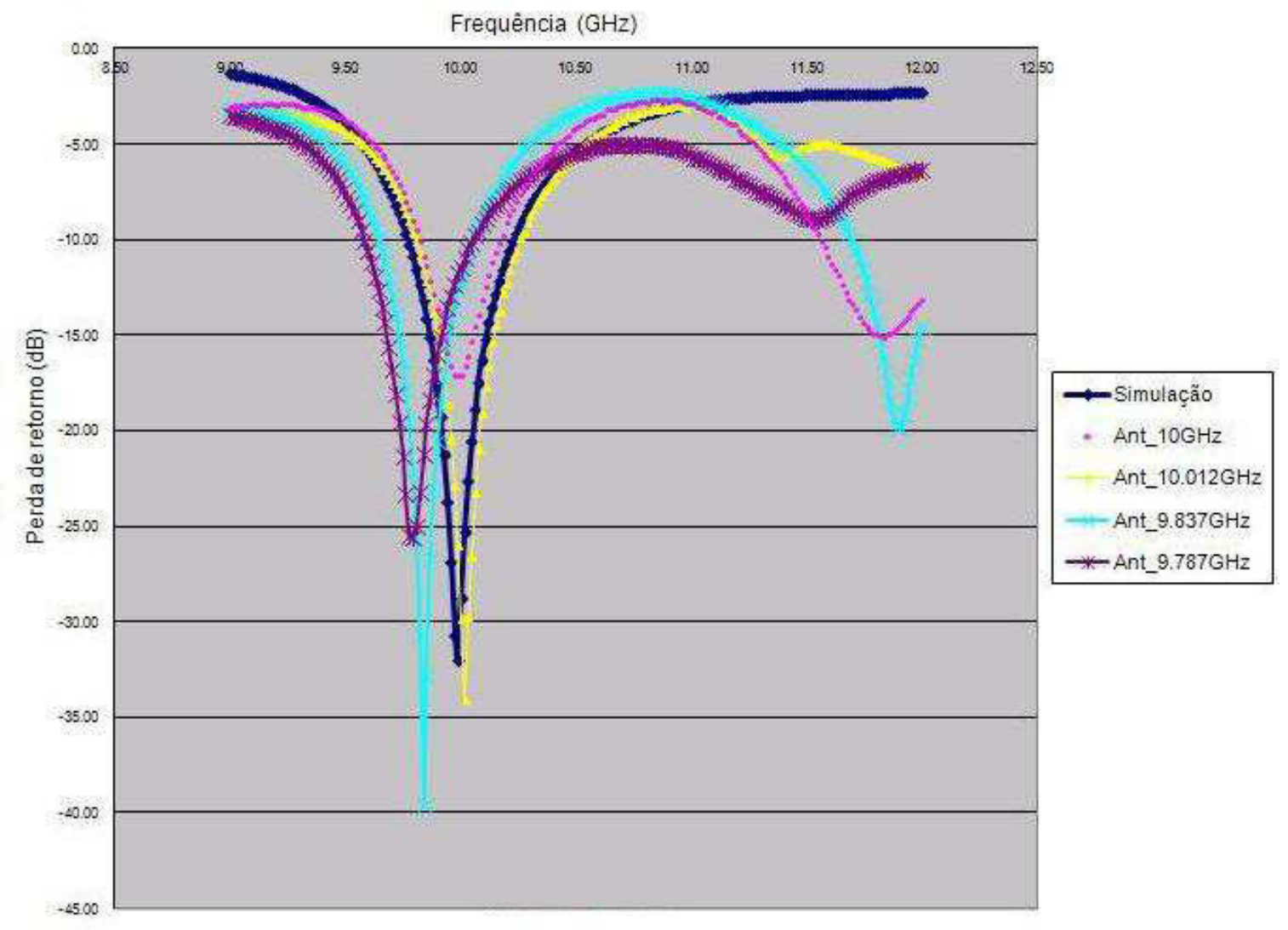

Figura 6.18: Simulação e medição da perda de retorno, em dB, para cada uma das antenas fabricadas para frequência aproximada de $10 \mathrm{GHz}$

mútuo. O array também foi realizado com o software Advanced Design System, onde a entrada de potência de cada antena foi realizada para um acoplamento de impedâncias de $50 \Omega$.

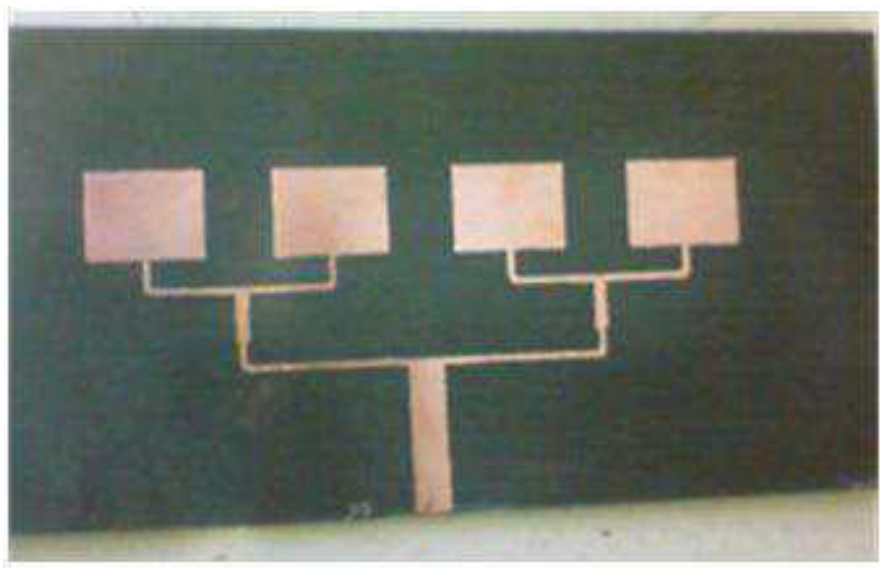

Figura 6.19: Array de 4 antenas fabricadas sobre o substrato RT5880 para uma frequência de $10 \mathrm{GHz}$ 


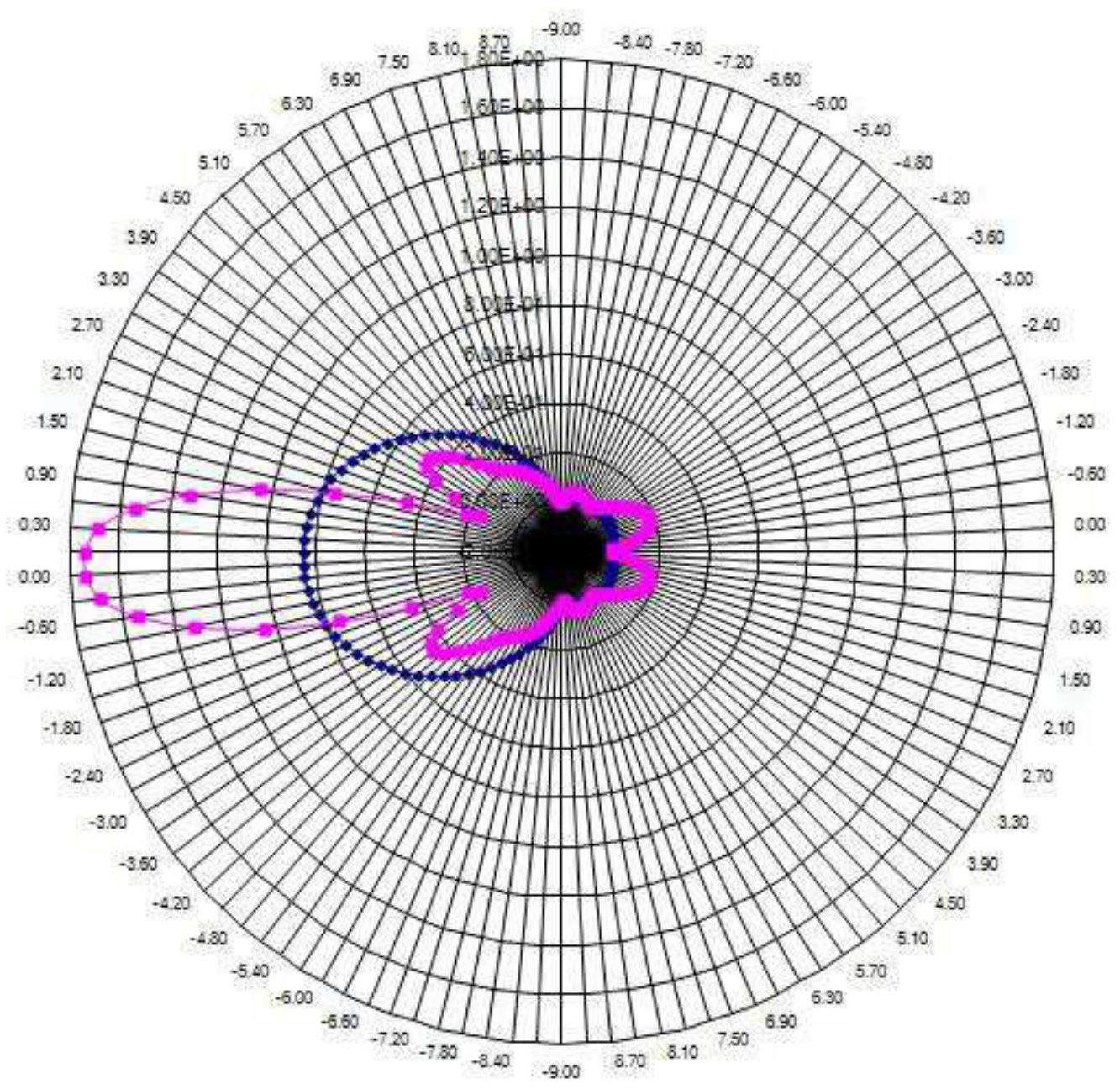

$\rightarrow-$ Ethets 1 antens
$\rightarrow-$ Ethets Array

Figura 6.20: Comparação da simulação do plano E entre uma antena de microfita e um array de 4 antenas de microfita para uma frequência de 10 $\mathrm{GHz}$, com igual substrato (RT5880

A partir da figura 6.20 , pode-se destacar a vantagem de utilizar o arranjo de antenas, o qual o feixe do sinal é muito mais diretivo e com uma maior potência do que utilizando apenas uma antena na transmissão. A devantagem com este arranjo é a entrada do sinal, porque, como mencionado anteriormente, a diversidade das antenas em um sistema MIMO é aproveitada para enviar pacotes independentes de informação através de cada uma delas (multiplexação espacial). Dado um arranjo com uma única entrada, só aumenta a diversidade em espaço mas não consegue fazer a multiplexação de informação.

Para montar o sistema e detetar, fisicamente, a distância mínima na qual as antenas não apresentam acoplamento mútuo e permaneçam descorrelatadas, foram realizadas medições com a ajuda do sistema de treinamento Lab Volt (Antenna Training and Measuring System 8092). A figura 6.21 apresenta o conteudo do kit para o desenvolvimento das medições. 


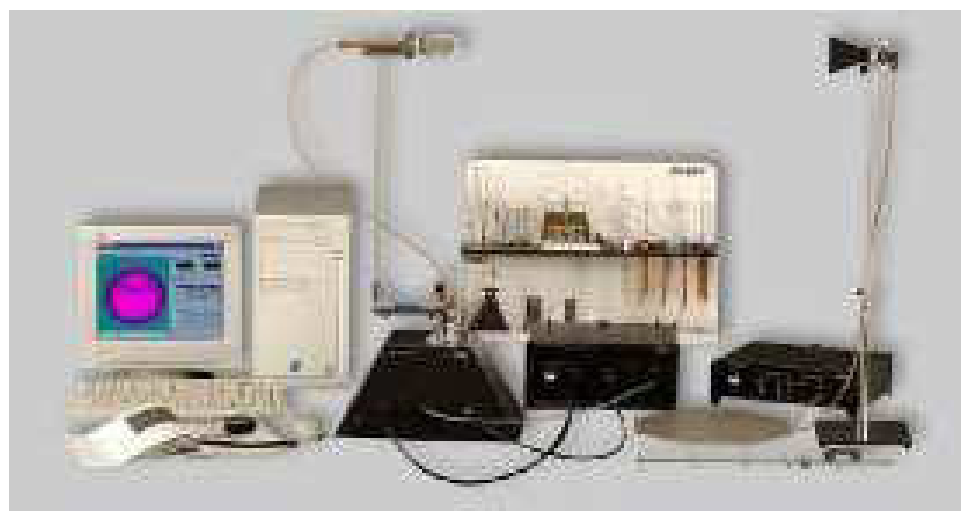

Figura 6.21: Sistema utilizado para fazer as medições de diagrama de radiação das antenas fabricadas

O sistema Lab Volt é projetado para a operação de baixa potência, para bandas de $1 \mathrm{GHz}$ e $10 \mathrm{GHz}$ (específicamente $915 \mathrm{MHz}$ e $10.5 \mathrm{GHz}$ ), permitindo medições das características da antena para estas faixas. A interface de aquisição de dados controla o posicionamento da antena e adquire o sinal da antena recebida. A figura 6.22 mostra o sistema montado

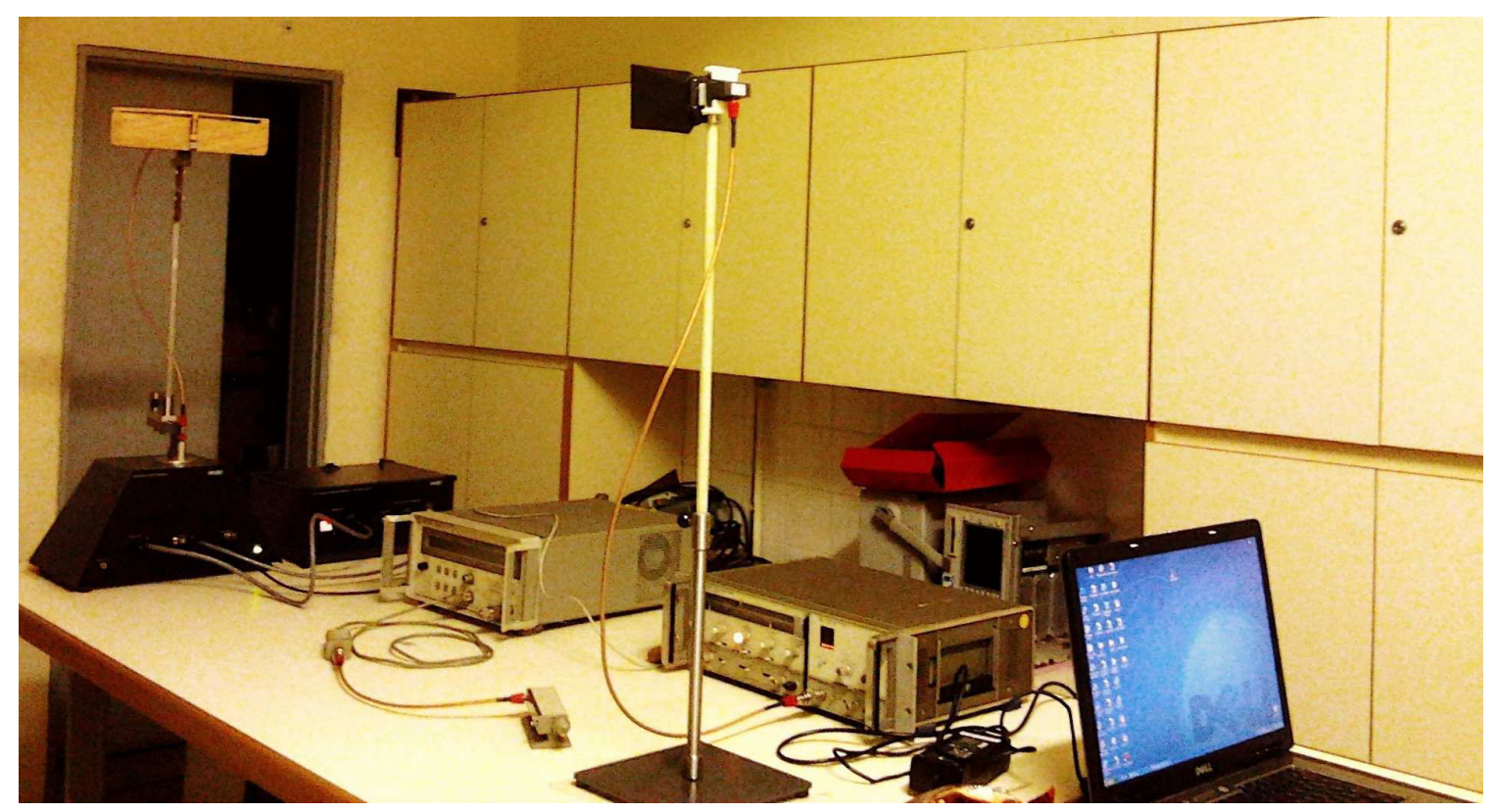

Figura 6.22: Montagem do kit do LabVolt para as medições das antenas desenvolvidas

A figura 6.23 detalha a montagem doas antenas a serem testadas, possibilitando a variação da distância entre elas para observar o efeito da correlação entre os sinais por ela recebidos. 


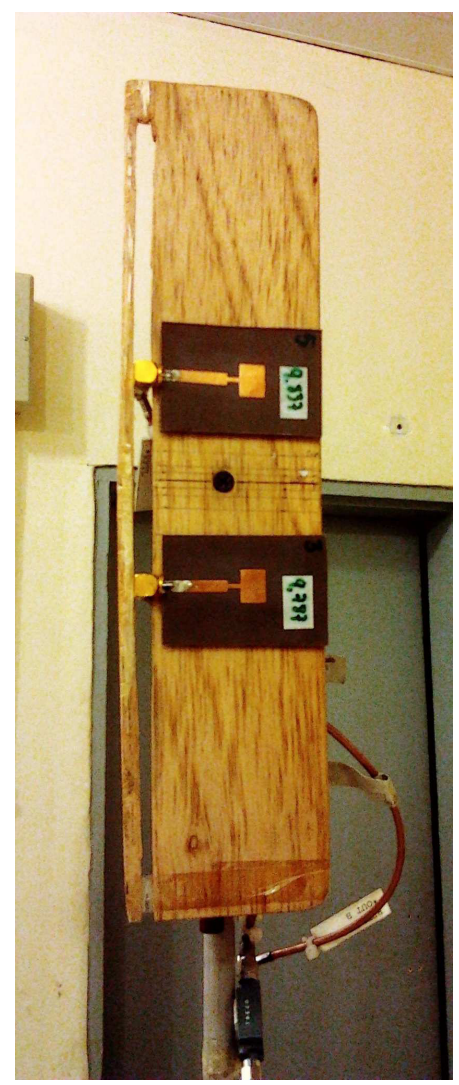

Figura 6.23: Montagem da medição de correlação entre duas antenas dependendo da distância

\section{Diagramas de radiação medidos}

As figuras de 6.24 até 6.28 são os diagramas de radiação em $2 \mathrm{D}$ e $3 \mathrm{D}$ das 4 antenas fabricadas e medidas no Analizador de Rede. Os diagramas foram feitos com o setup de medições LabVolt. Pode-se observar comparando o diagrama de cada uma das antenas com o diagrama de radiação do array da figura 6.28, que tendo múltiplas antenas a diretividade é melhor, pois cada uma das 4 antenas apresenta o máximo entre 8 e $10 \mathrm{~dB}$, enquanto o array apresenta o máximo no entorno de $5 \mathrm{~dB}$ acima, acarretando em uma diretividade $5 \mathrm{~dB}$ acima da antena isoladade $(14.5 \mathrm{~dB})$.

A figura 6.29 ilustra as diferenças nos plano $\mathrm{E}$ e $\mathrm{H}$ dos diagramas de radiação entre duas antenas conectadas a um divisor de potência, para umas distâncias de separação de $\lambda / 2,1.33 \lambda, 1.5 \lambda, 2.66 \lambda, 4 \lambda$. Uma melhoría nos lóbulos laterais pode ser vista a medida que as antenas vão sendo afastadas. 


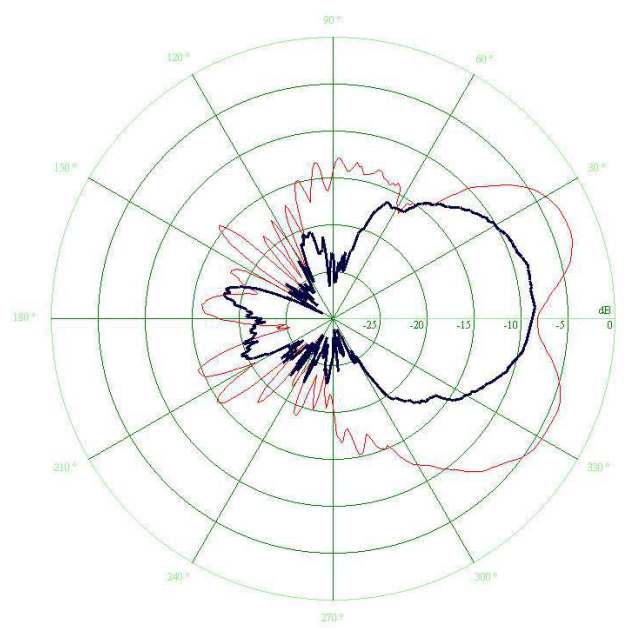

6.24(a): Diagrama 2D

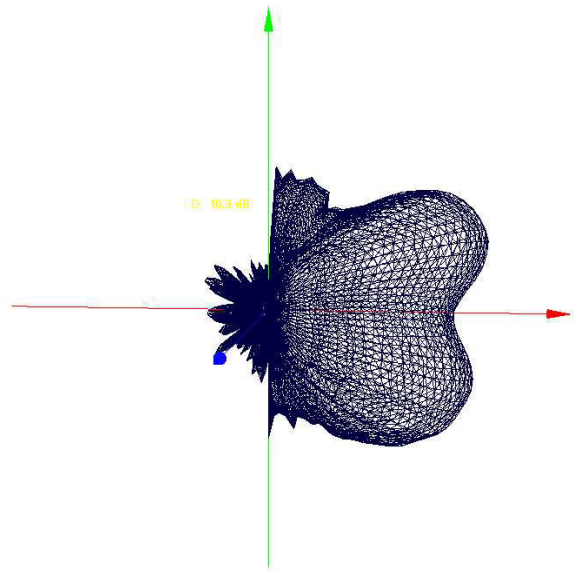

6.24(b): Diagrama 3D

Figura 6.24: Diagrama de radiação da Antena 1

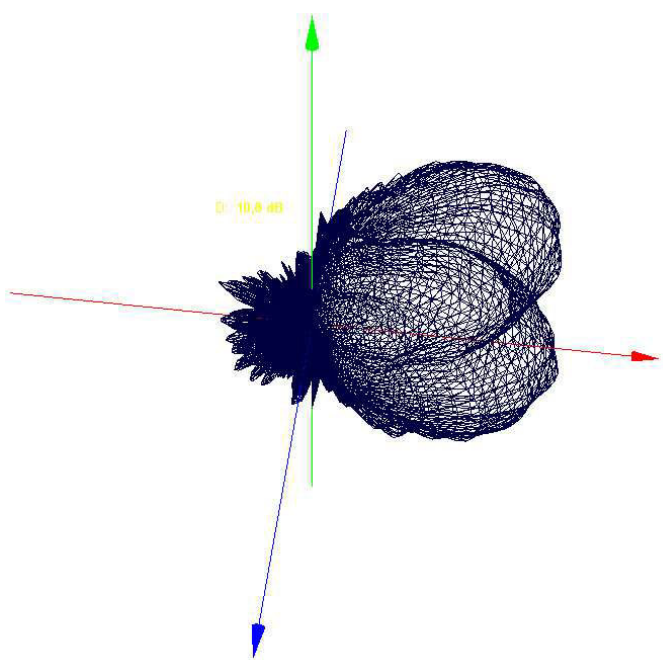

6.25(b): Diagrama 3D

Figura 6.25: Diagrama de radiação da Antena 2

\section{6}

\section{Conclusões}

No capítulo apresentado, foram mostrados os resultados de taxa de erro de bit, capacidade e diagrama de radiação das antenas do sistema configurado para duas antenas transmissoras e duas receptoras, mediante a utilização de blocos en VHDL para uma futura implementação em placas FPGA. Foi mostrado como a capacidade variou de acordo com o aumento da relação sinalruído e a vantagem de um sistema 2x2 frente a un sistema simples, como é o sistema SISO, e os sistemas SIMO e MISO. 


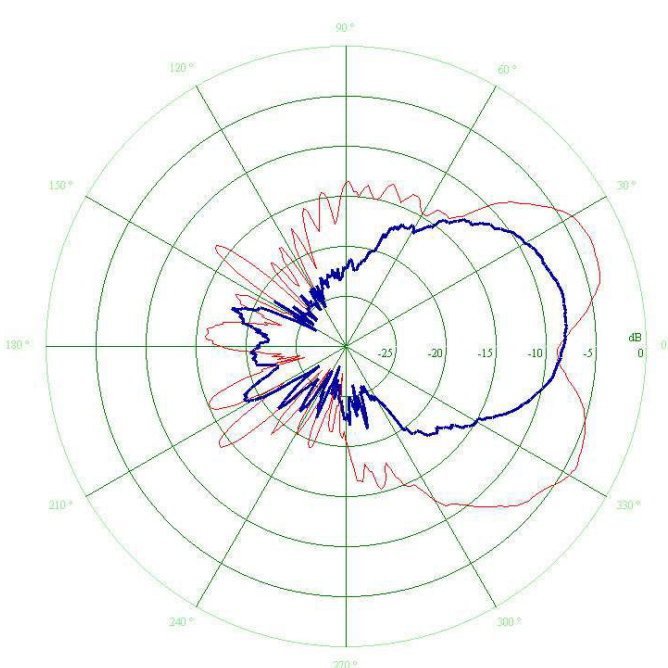

6.26(a): Diagrama 2D

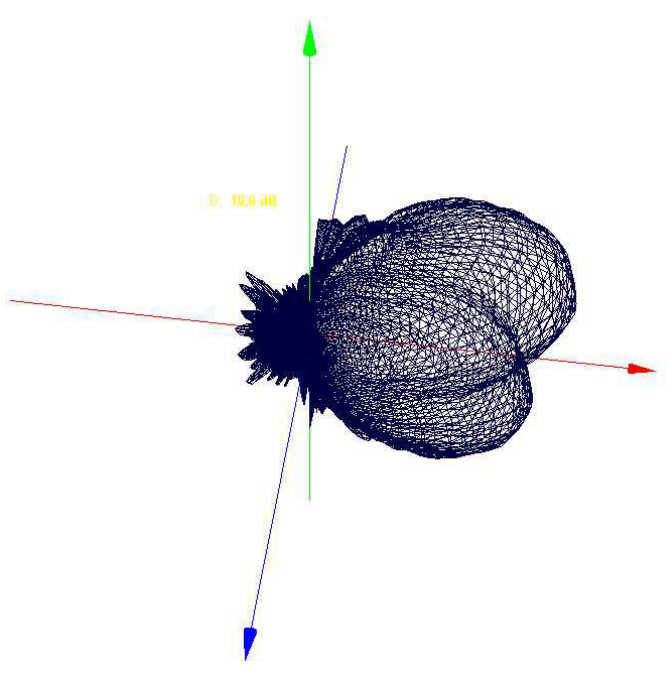

6.26(b): Diagrama 3D

Figura 6.26: Diagrama de radiação da Antena 3

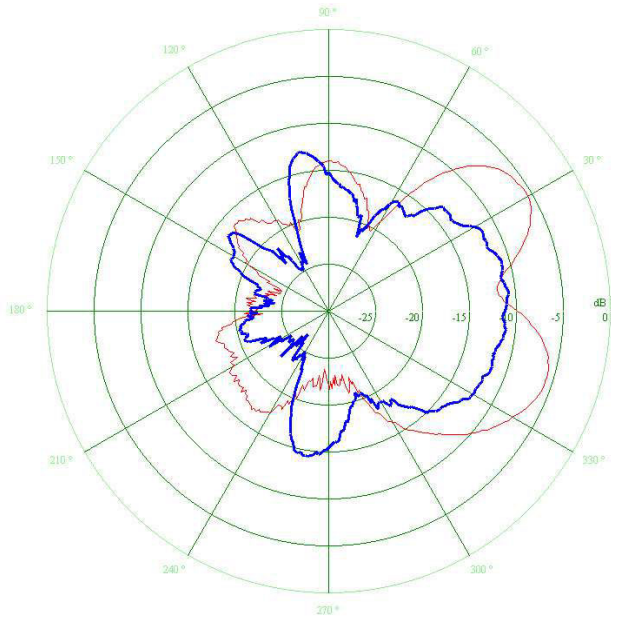

6.27(a): Diagrama 2D

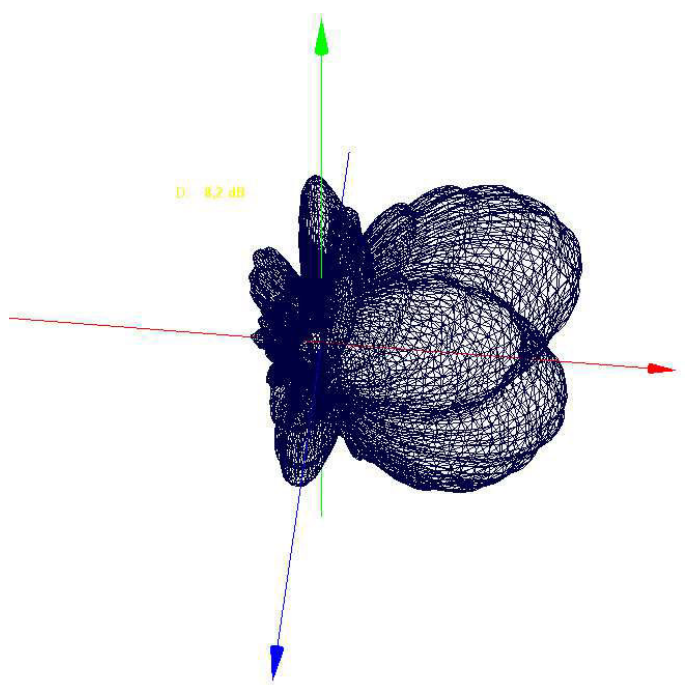

6.27(b): Diagrama 3D

Figura 6.27: Diagrama de radiação da Antena 4 


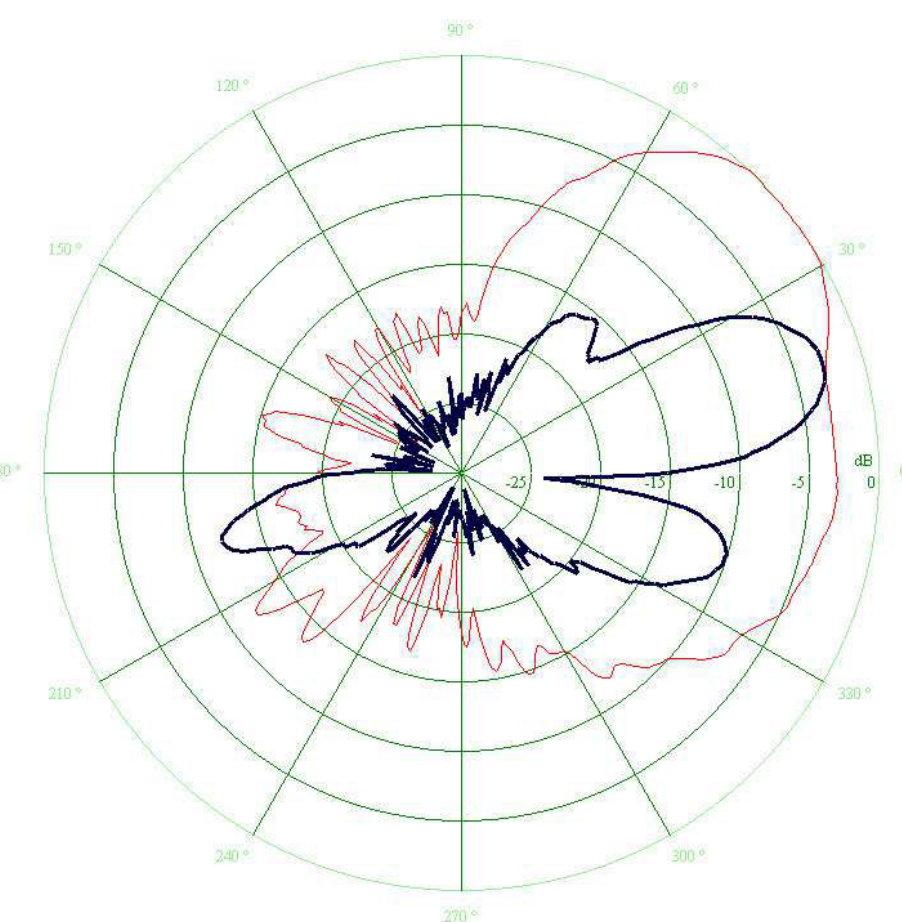

6.28(a): Diagrama 2D

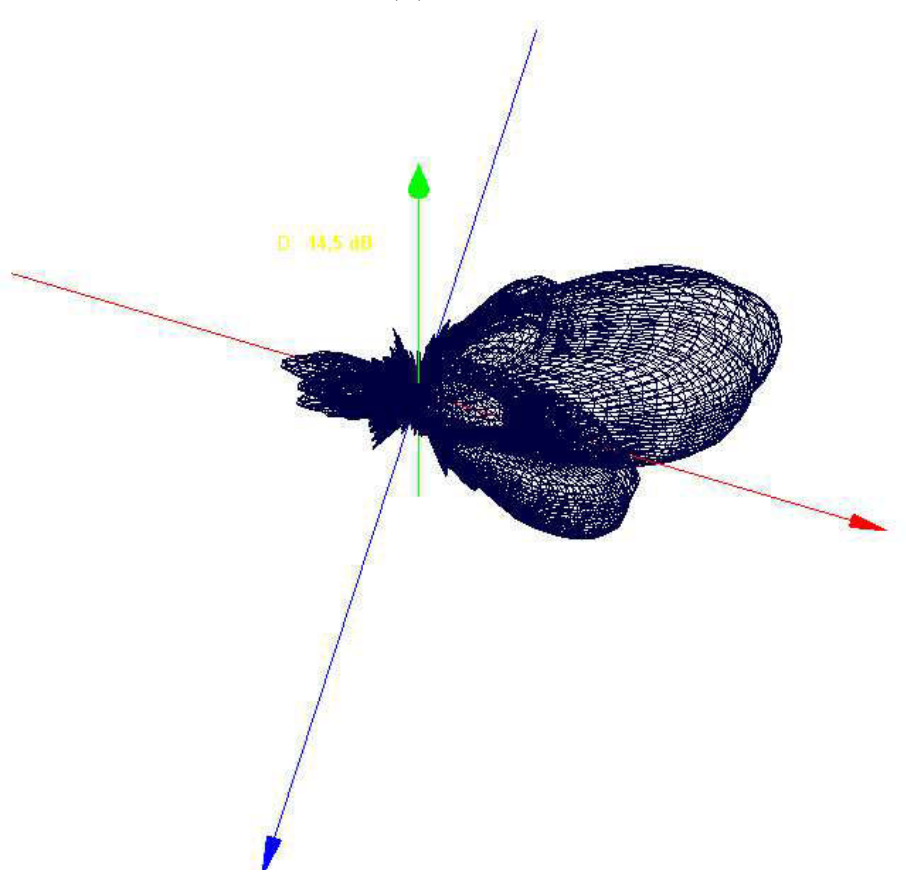

6.28(b): Diagrama 3D

Figura 6.28: Diagrama de radiação do Array de 4 antenas 


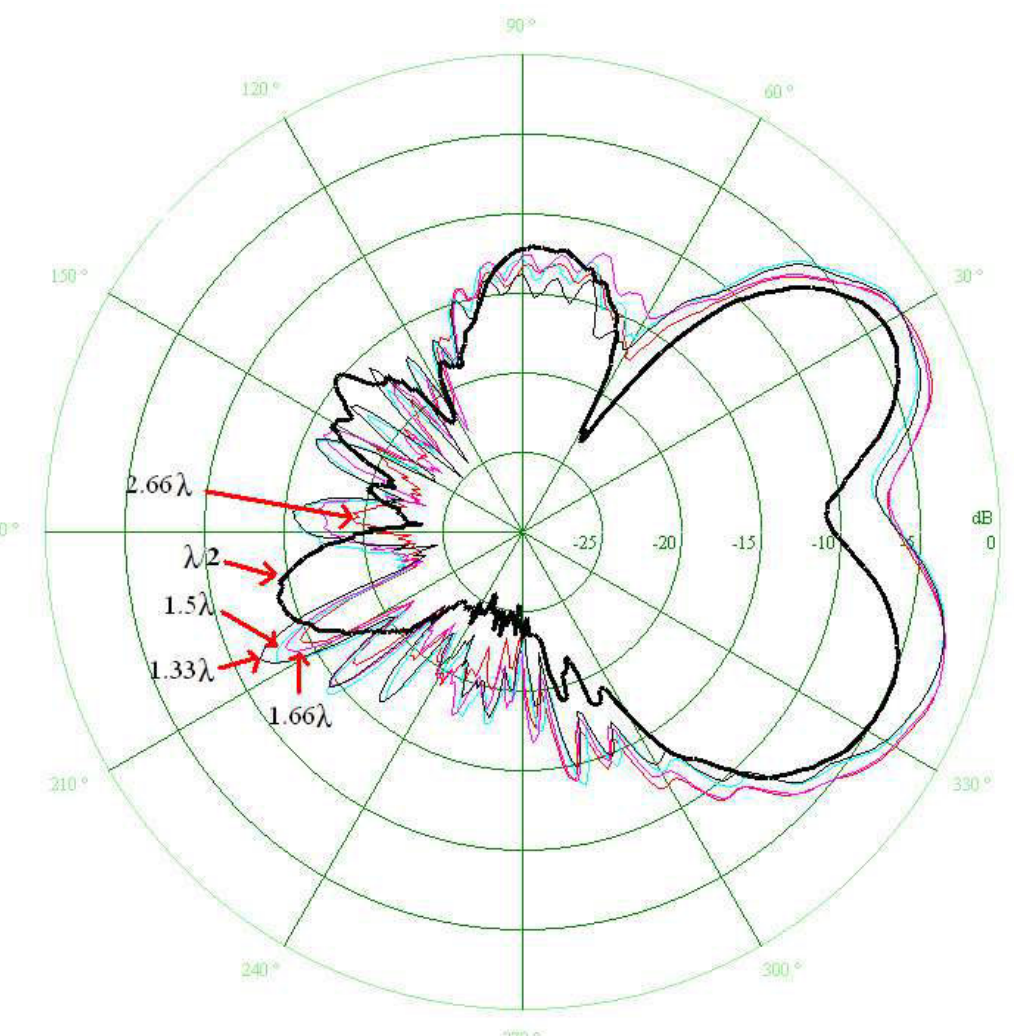

6.29(a): Plano E

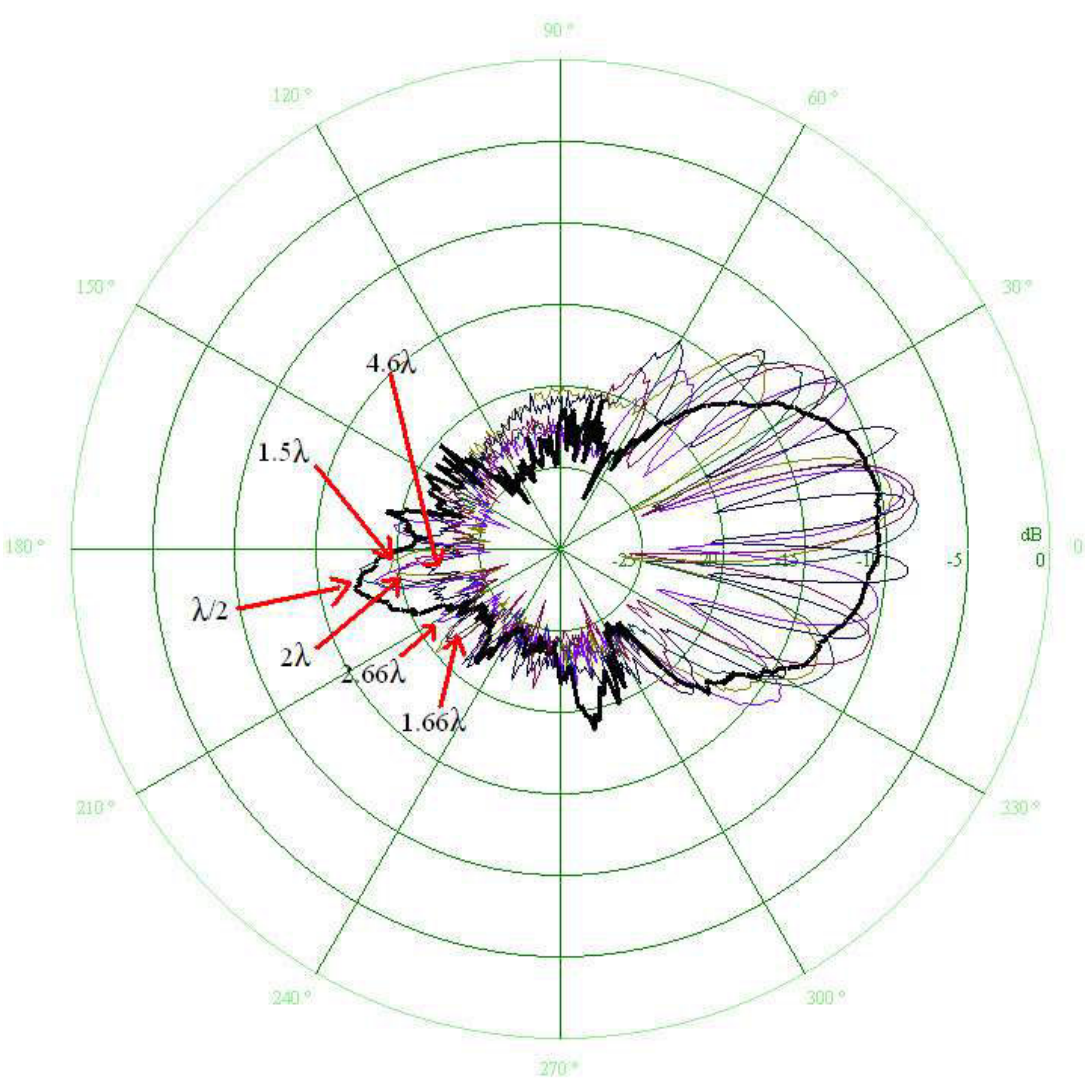

6.29(b): Plano H

Figura 6.29: Comparação entre diagramas de radiação de acordo com as distâncias de separação entre duas antenas 


\section{7 \\ Comentários finais e conclusões}

Ao longo do presente capítulo serão apresentados os resultados obtidos no desenvolvimento do sistema MIMO 2x2, realizados utilizando a tecnologia de circuitos digitais logicamente programáveis (FPGA) e linguagem em VHDL.

O sistema realizado baseia-se na teoria da mitigação do desvanecimento encontrado em qualquer ambiente de propagação de um sistema wireless, utilizando a técnica de diversidade espacial, utilizando duas antenas transmissoras e duas receptoras no lugar de apenas 1 transmissora e 1 receptora e aplicando a teoria de multiplexação espacial para o aproveitamento do canal. Desta forma o setup simulado no SystemVue apresenta resultados satisfatórios e a informação gerada foi transmitida na metade do tempo.

Foi simulado um ambiente Rayleigh de desvanecimento plano para testar o sistema realizado, onde em cada entrada do receptor chegou uma mistura dos sinais transmitidos.

Com a ajuda do equalizador de Mínimo Erro Quadrático Médio (MMSE), os sinais misturados que chegaram às entradas do receptor foram separados e as interferências e o ruido foram minimizados, para depois decidir o nível lógico a ser reconstruído.

A partir desses comentários e dos resultados obtidos, podem ser destacados os seguintes itens:

- Simplificação na implementação de um sistema MIMO mediante programação em VHDL e a sua implementação em FPGAs, no que, das características da placa, o sistema todo pode ser implementado com uma placa FPGA DSP (Digital Signal Processing) apenas.

- Os testes realizados por meio da ferramenta computacional da Agilent (SystemVue) permitiram uma excelente avaliação dos transmissores e 
receptores MIMO, assim como a caracterização do canal, apresentando resultados de simulação satisfatórios, permitindo que a tecnología MIMO em FPGA DSP possa ser aplicada a qualquer faixa de frequência, devido ao desenvolvimento e modelagem dos algoritmos realizados em banda básica.

- A capacidade do sistema 2x2 foi aumentando de forma logarítmica, onde atingiu um valor de $2.1 \mathrm{bits} / \mathrm{s} / \mathrm{Hz}$ a cada $3 \mathrm{~dB}$ de aumento na relação sinal;ruido, enquanto os outros sistemas comparados $(1 \times 1,2 \times 1,1 \times 2)$ não conseguiram chegar ao $1 \mathrm{bit} / \mathrm{s} / \mathrm{Hz}$. Desta forma, pode se mostrar que para um certo valor de capacidade, o sistema MIMO 2x2 diminui a necessidade de fornecer altos níveis de relação sinal-ruido.

- Este trabalho apresentou, ainda, a caracterização de antenas planares com resultados simulados próximos aos experimentais, garantindo a aplicação destas antenas no sistema MIMO, incluindo a caracterização de um array de 4 antenas descorrelatadas.

\section{1}

\section{Trabalhos futuros}

Os procedimentos de simulação e desenvolvimento dos algoritmos em circuitos logicamente programáveis (FPGA) para os transmissores e receptores MIMO, assim como a realização e a caracterização das antenas planares, e do array de antenas, permitem que uma nova sistemática de projeto MIMO seja elaborada, garantindo uma boa eficiência e uma baixa SNR nos modelos considerados.

Objetivando a realização do setup de MIMO simulado neste trabalho, uma melhor avaliação do estimador de canal no bloco do receptor poderá sofrer modificações durante as etapas de implementação futura do sistema.

Também uma etapa em RF, como osciladores, mixers, amplificadores de potência e LNAs, devem ser adicionadas para transmitir e receber a informação enviada pelo transmissor na faixa de frequência requerida, neste caso, as antenas fabricadas em $10 \mathrm{GHz}$ formarão parte desta etapa conforme propõe a figura 7.1 .

No caso de se utilizar um número maior de antenas no sistema a ser realizado, deve se prever a necessidade de implementar uma placa FPGA DSP 


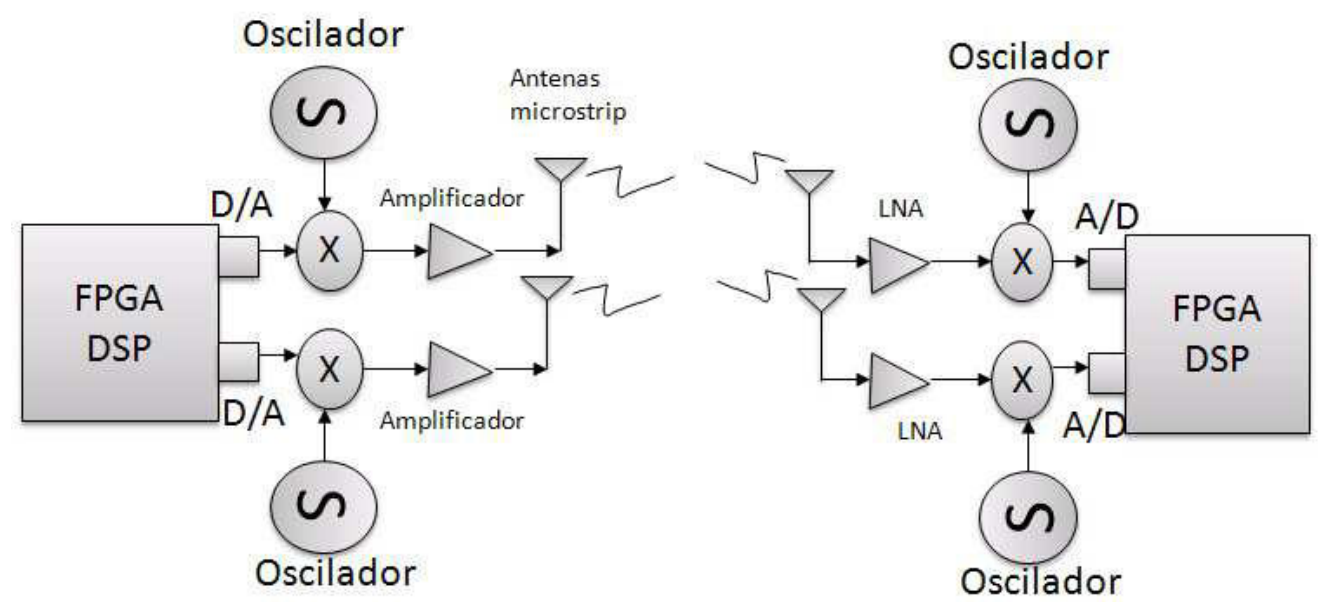

Figura 7.1: Esquema de transmissão e recepção do sistema MIMO proposto

com um maior número de conversores A/D e D/A, referentes ao número de antenas a serem utilizadas. 


\section{Referências Bibliográficas}

[1] Sharony, Jacob. Introduction to Wireless MIMO - Theory and Applications . CEWIT. 2006

http://www.ieee.li/pdf/viewgraphs/wireless_mimo.pdf

[2] Datacomm Research Company. Using MIMO-OFDM Tecnhology to Boost Wireless LAN Performance Today. 2005.

[3] Goldsmith, Andrea. Wireless Communications. Editorial Cambridge University Press. 2005.

[4] Telatar, I. Emre. Capacity of Multi-antenna Gaussian Channels. European Transactions on Telecommunications. 1999. p585-595

[5] Pimentel, Renato Alfonso. Diversidades em espaço e polarização aplicadas a sistemas móveis celulares urbanos. Dissertação de Mestrado. PUC - Rio. 30 de setembro de 1999.

[6] Srivastava, Neelam. Diversity Schemes For Wireless Communication. A short Review. Journal of Theoretical and Applied Information Technology. May 31th 2010. p134-142.

[7] Giannakis Zhiqiang Liu, X. M. G. B; Zhou, S. Space Time Coding for Broadband Wireless Communications.Editorial Cambridge University Press. 2007.

[8] Guimarães, Dayan; Gomes, Geraldo. Caracterização do canal para o MISBTVD. INATEL. Set 2006.

[9] Krishna Sankar. Rayleigh Multipath Channel Model. 2008. http://www.dsplog.com

[10] Vcelak, Jan; Javornik, Tomaz; Syjora, Jan; Kandus. Gorazd; Plevel, Sreco. Multiple-Input Multiple Output Wireless Systems. Electronical Review. 2003. p234-239. 
[11] Halperin, Daniel; Hu, Wenjun; Sheth, Anmol; Wetherall, David. 802.11 with Multiple Antennas for Dummies. Computer Communication Review.

[12] Nuaymi, Loufti. WiMAx: Technology for Broadband Wireless Access. Editorial Wiley. 2007.

[13] Andrews, Jeffrey G; Ghosh, Arunabha; Muhamed, Rias. Fundamentals of Wimax. Understanding Broadband Wireless Networking. Editorial Prentice Hall. 2007.

[14] Sibille, Alain; Oestges, Claude; Zanella, Alberto. MIMO From Theory to Implementation. Editorial Elsevier.

[15] Oestges, Claude; Clerckx, Bruno. MIMO Wireless Communication. From Real-World Propagation to Space-Time Code Design. Editorial Elsevier.

[16] Burg, A; Haene, S et al Algorithm and VLSI Architecture for Linear MMSE Detection in MIMO-OFDM Systems. IEEE International Symposium on Circuits and Systems. 2006

[17] Tse, David; Viswanath, Pramod. Fundamentals of Wireless Communication. Editorial Cambridge University Press. 2005

[18] Balanis, Constantine. Antenna Theory. Analysis and Design. Editorial Wiley. Hoboken, New Jersey. 2005.

[19] Lo, Y; Lee, S. W. Antenna Handbook. Editorial Van Nostrand Reinhold. Vol II. New York. 1993

[20] Michigan Technological University. Smart Antennas. 2001. http://www.oocities.org/hamsadhwani8/smartantennas/index.html

[21] Wu, Di; Eilert Johan; Liu, Dake. Implementation of a High-Speed MIMO Soft-Output Symbol Detector for Software Defined Radio.

[22] High Frequency Structural Simulator (HFSS). http://www.ansys.com

[23] Advanced Design System (ADS).

www.home.agilent.com/agilent/product.jspx?nid=-34346.0.00\&cc= BR\&lc $=$ por $\}$

[24] SystemVue Electronic System-Level (ESL) Design Software.

wWw . home.agilent. com/agilent/product. j spx?cc=BR\&lc=por\&ckey=12 97131\&nid $=-34264.0 .00 \& i d=1297131\}$ 
[25] Lab-Volt. http://www.labvolt.com

[26] Matlab. http://www.mathworks.com/products/matlab

[27] Xilinx ISE Design Suite. http://www.xilinx.com 
A
Anexo

\section{Divisor de potência}

Como o sistema de treinamento só funciona para usar uma antena por vez, se desenhou um divisor de potência com a ajuda do software ADS permitindo utilizar as 4 antenas simultaneamente. A figura A.1 mostra o desenho deste divisor de potência.

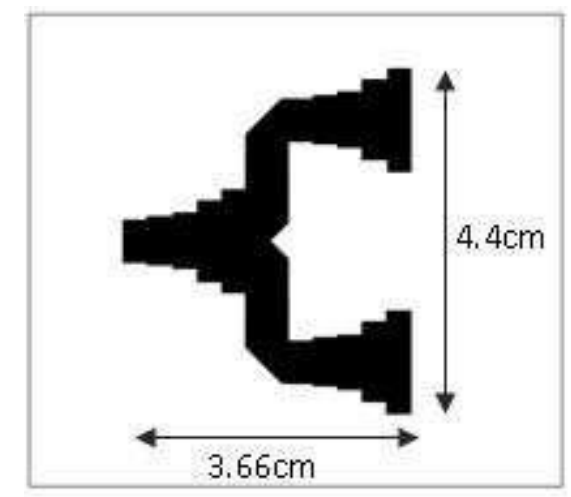

Figura A.1: Divisor de potência

A entrada é de $50 \Omega$ e cada porta de saida $25 \Omega$, na qual foram colocados dois conectores em cada um, de modo que corresponda a cada conector uma antena de $50 \Omega$.

Por motivos de medições, as antenas foram conectadas por cabos SMA, porque estes cabos permitem que a distância entre as antenas poda ser alterada com a finalidade de se testar a descorrelação entre elas.

A figura A.2 apresenta a perda de retorno (s11)medida em dB. 


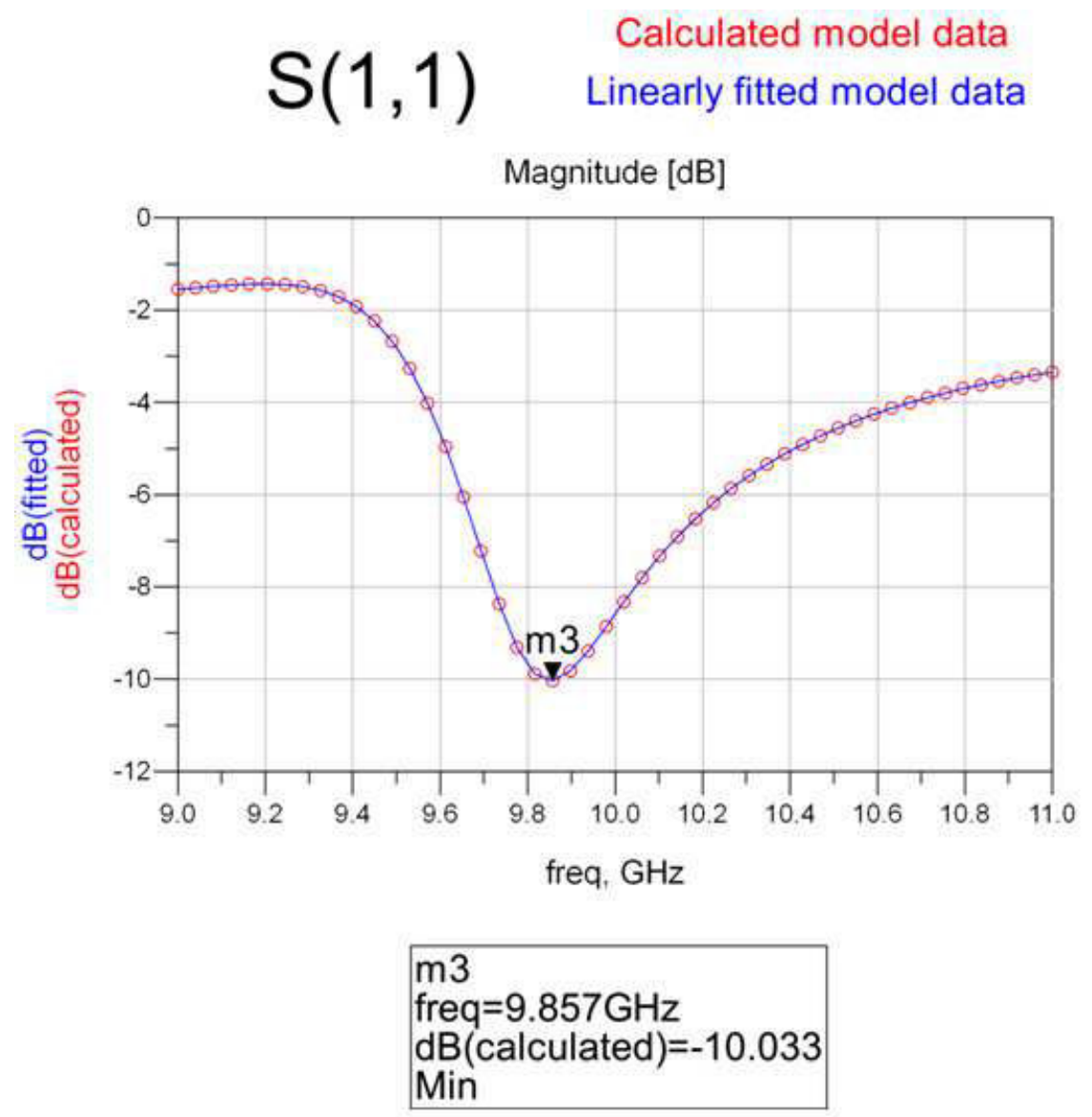

Figura A.2: Simulação do S11 do divisor de potência no software ADS 